\title{
WestVirginiaUniversity
}

THE RESEARCH REPOSITORY @ WVU

Graduate Theses, Dissertations, and Problem Reports

2013

\section{Using bio-chars as potential catalysts for upgrading wood pyrolysis vapors}

Wenjia Jin

West Virginia University

Follow this and additional works at: https://researchrepository.wvu.edu/etd

\section{Recommended Citation}

Jin, Wenjia, "Using bio-chars as potential catalysts for upgrading wood pyrolysis vapors" (2013). Graduate Theses, Dissertations, and Problem Reports. 402.

https://researchrepository.wvu.edu/etd/402

This Thesis is protected by copyright and/or related rights. It has been brought to you by the The Research Repository @ WVU with permission from the rights-holder(s). You are free to use this Thesis in any way that is permitted by the copyright and related rights legislation that applies to your use. For other uses you must obtain permission from the rights-holder(s) directly, unless additional rights are indicated by a Creative Commons license in the record and/ or on the work itself. This Thesis has been accepted for inclusion in WVU Graduate Theses, Dissertations, and Problem Reports collection by an authorized administrator of The Research Repository @ WVU. For more information, please contact researchrepository@mail.wvu.edu. 


\title{
USING BIO-CHARS AS POTENTIAL CATALYSTS FOR UPGRADING WOOD
} PYROLYSIS VAPORS

\author{
Wenjia Jin \\ Thesis submitted to the \\ Davis College of Agriculture, Natural Resources and Design \\ at West Virginia University \\ in partial of the requirements \\ for the degree of
}

\author{
Master of Science \\ in \\ Forestry
}

\begin{abstract}
Approved by
Kaushlendra Singh, Ph.D., Committee Chairperson Jingxin Wang, Ph.D.

John Zondlo, Ph.D.

Wood Science and Technology Program, Division of Forestry and Natural Resources,

Davis College of Agriculture, Natural Resources and Design

West Virginia University, Morgantown, West Virginia

2013
\end{abstract}

Keywords: Catalytic Pyrolysis, Bio-oil, Bio-char, Woody biomass, Activation energy Copyright 2013 Wenjia Jin 


\title{
ABSTRACT \\ USING BIO-CHARS AS POTENTIAL CATALYSTS FOR UPGRADING WOOD PYROLYSIS VAPORS
}

\begin{abstract}
Wenjia Jin
Pyrolysis is a promising thermochemical conversion method to process lignocellulosic biomass to produce bio-oil that can be further refined into chemicals and fuels compatible with current petrochemical fuels. However, bio-oils are highly reactive and unstable and therefore must be refined immediately, thereby reducing process sustainability. Catalytic modifications of pyrolysis vapors have been researched to improve bio-oil stability. However, using traditional highly active petroleum refining cracking catalysts for catalytic pyrolysis has shown some negative results, for example, increasing biooil moisture content and reducing its calorific value. Therefore, this project aims at understanding decomposition behavior of wood components, its chemical constituent polymers and using moderate catalysts, like bio-chars.
\end{abstract}

Thermo-chemical decomposition behavior for wood components (bark, sapwood and heartwood) and individual wood-polymers (cellulose, hemicellulose and lignin) of typical hardwood is presented. Two hardwood species, namely red oak and yellow-poplar, were separated into their bark, sapwood and heartwood components. The samples were tested for calorific value, specific gravity, proximate analysis, mineral composition, chemical composition, ultimate analysis, and thermo-chemical decomposition behavior. In addition, the thermo-chemical decomposition behaviors of cellulose, xylan, and lignin polymers were tested. The activation energy was calculated for various fractional conversion values using the isoconversion method. The results showed that char yields from lignin, cellulose and xylan polymers were $41.43 \%, 4.45 \%$ and $1.89 \%$, respectively, at the end of pyrolysis. Furthermore, cellulose, xylan and lignin polymers decomposed dramatically in the temperature ranges of $320^{\circ} \mathrm{C}$ to $360{ }^{\circ} \mathrm{C}, 150{ }^{\circ} \mathrm{C}$ to $230{ }^{\circ} \mathrm{C}$ and $100{ }^{\circ} \mathrm{C}$ to $410{ }^{\circ} \mathrm{C}$, respectively, with decomposition peaks at $340{ }^{\circ} \mathrm{C}, 200$ ${ }^{\circ} \mathrm{C}$ and $340^{\circ} \mathrm{C}$, respectively. In addition, the maximum activation energy for cellulose was $381 \mathrm{~kJ} / \mathrm{mol}$ at $360{ }^{\circ} \mathrm{C}$ and for xylan it was $348 \mathrm{~kJ} / \mathrm{mol}$ at $210^{\circ} \mathrm{C}$.

Catalytic performance of catalysts switchgrass bio-char and red oak bark bio-char during vapor upgrading pyrolysis are documented. The clean woodchip was pyrolyzed with and without vapor upgrading under atmosphere pressure at the target temperature of $500{ }^{\circ} \mathrm{C}$. The catalysts showed significant positive effects on the bio-oil yields, moisture content and $\mathrm{pH}$ value of bio-oils. However, the vapor upgrading process significantly decreased the carbon yield of bio-oil when using switchgrass biochar as catalyst. The bio-oil yield decreased from $49.31 \%$ (no catalyst) to $44.81 \%$ (switchgrass bio-char catalyst) and to $48.68 \%$ (red oak bark bio-char catalyst). The lost mass of bio-oil ended-up in the gaseous phase as reflected in hydrogen, carbon dioxide, and carbon monoxide content. As result, at $400^{\circ} \mathrm{C}$, hydrogen content increased from $0.82 \%$ to $3.74 \%$, carbon dioxide content increased from $21.16 \%$ to $32.33 \%$, and carbon monoxide content increased from $16.49 \%$ to $23.19 \%$ for switchgrass bio-char catalyst compared to no catalyst pyrolysis. 


\section{TABLE OF CONTENTS}

ABSTRACT
TABLE OF CONTENTS
LIST OF FIGURES
LIST OF TABLES
CHAPTER 1: INTRODUCTION
1.1. Pyrolysis Process
1.2. Anatomy of Biomass
1.3. Pyrolysis Products
1.5. Objectives

CHAPTER 2: PYROLYSIS KINETICS OF PHYSICAL COMPONENTS OF WOOD AND WOOD-POLYMERS USING ISOCONVERSION METHOD .............................. 12

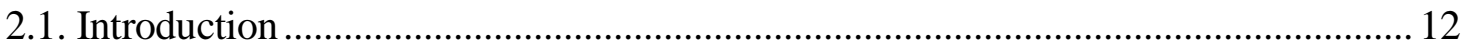

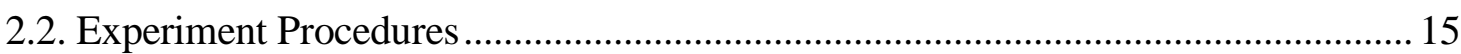

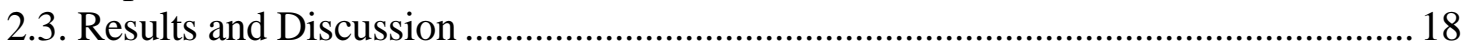

2.3.1. Feedstock Characterization............................................................................. 18

2.3.2. Thermo-Chemical Decomposition Behavior of Cellulose, Xylan, and Lignin .....26

2.3.3. Thermo-Chemical Decomposition Behavior of Wood Components ........................ 31

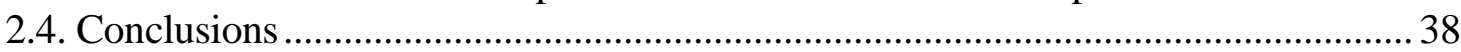

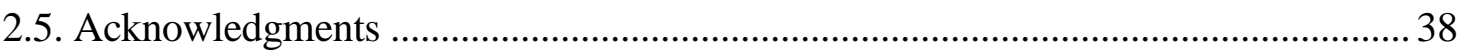

References ................................................................................................... 39

CHAPTER 3: CATALYTIC UPGRADING OF PYROLYSIS VAPORS USING BIOCHARS AS CATALYST .................................................................................... 43

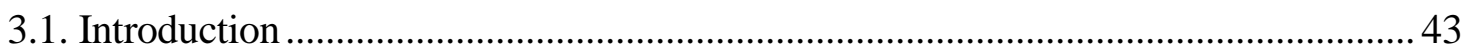

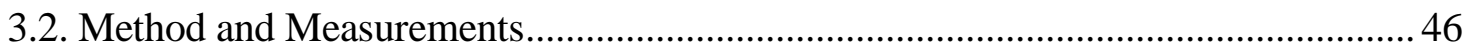

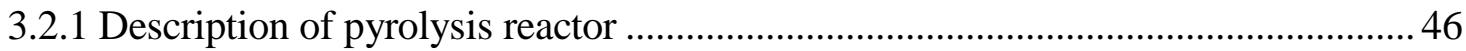

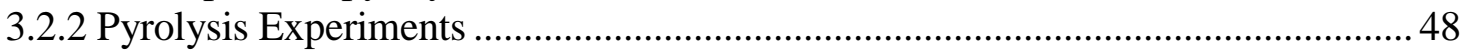

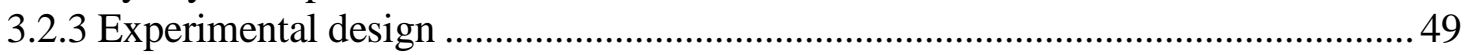

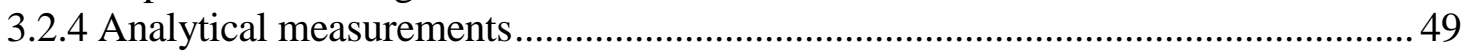

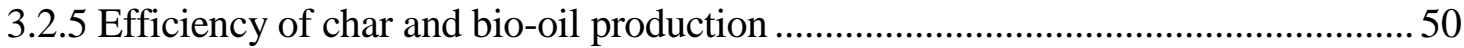

3. 3. Results and Discussion ......................................................................................... 51

3.3.1. Feedstock Biomass and Bio-char Catalyst Characterization..................................51

3.3.2 Effect of Type of Bio-Char Catalysts...................................................................5

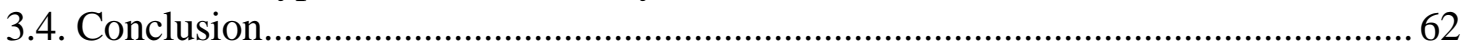

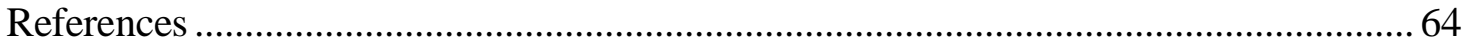

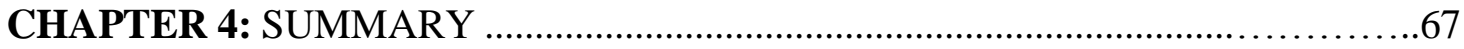




\section{LIST OF FIGURES}

Figure 1.1 Chemical structure of cellulose....................................

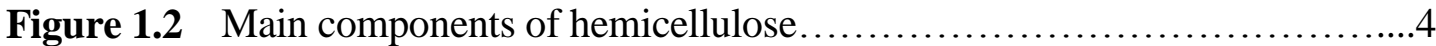

Figure 1.3 p-Coumaryl, coniferyl, and sinapyl structures and resonance hybrid structures of phenoxy radicals produced by the oxidation of coniferyl...6

Figure 2.1 Yellow-poplar and red oak samples showing bark, sapwood and heartwood........................................................

Figure 2.2 Percent cellulose, hemicellulose and lignin contents (d.b.) in bark, sapwood and heartwood of red oak and yellow-poplar samples....................................................24

Figure 2.3 Thermo-gravimetric analysis results showing (a) TGA-percentage weight remaining, and (b) DTG-rate of fractional changes when samples of cellulose, xylan and lignin are heated from $50^{\circ} \mathrm{C}$ to $700^{\circ} \mathrm{C}$ at the heating rate of $10^{\circ} \mathrm{C} / \mathrm{min}$ under an inert atmosphere $\ldots \ldots \ldots \ldots \ldots \ldots \ldots \ldots \ldots . .28$

Figure 2.4 Activation energy and dX/dt curves of (a) cellulose, (b) xylan and (c) kraft lignin as a function of fractional conversion from 0.01 to 0.9. 31

Figure 2.5 Thermo-gravimetric analysis results showing rate of percentage weight remaining when samples of (a) yellow-poplar and (c) red oak's components (bark, sapwood and heartwood), and rate of fractional changes when samples (b) yellow-poplar and (d) red oak's components (bark, sapwood and heartwood) heated from $50^{\circ} \mathrm{C}$ to $700^{\circ} \mathrm{C}$ at the heating 
rate of $10^{\circ} \mathrm{C} / \mathrm{min}$ under an inert atmosphere.

Figure 2.6 Activation energy and dX/dt (experimental and calculated) curve of (a) bark, (b) heartwood and (c) sapwood of yellow-poplar as a function of

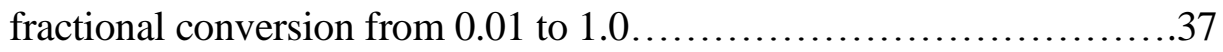

Figure 3.1 Experimental set-up used in pyrolysis includes pyrolysis reactor holding biomass, nitrogen flow, location of thermocouple, and set of condensers................................................47 


\section{LIST OF TABLES}

Table 1.1 Performance properties of petroleum industry catalysts (FCC, ZSM-5 and mental oxidized ZSM-5) ....................................

Table 2.1 Calorific value and cell wall specific gravity measurements (mean \pm standard deviation, 2 replications, 2 measurements on each replication) for samples of yellow-poplar and red oak's components (bark, sapwood and heartwood) and wood-polymers...............................19

Table 2.2 Ultimate analysis (carbon, hydrogen, nitrogen and sulfur content) of bark, sapwood, and heartwood of red oak and yellow-poplar and wood-

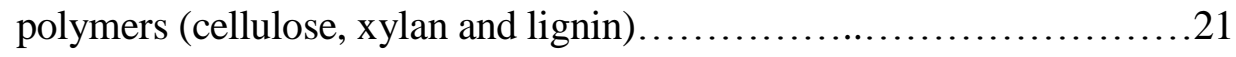

Table 2.3 Mineral composition in parts per million (ppm) of the physical components (sapwood, heartwood, bark) of red oak and yellowpoplar.

Table 2.4 Proximate analysis (moisture, ash, volatile and fixed carbon (\% d.b.)) of bark, sapwood, and heartwood of red oak and yellow-poplar and woodpolymers (cellulose, xylan and lignin).

Table 2.5 Percent cellulose, hemicellulose and lignin contents (d.b.) in bark, sapwood and heartwood of red oak and yellow-poplar samples..........25

Table 3.1 Ultimate analysis (carbon, hydrogen, nitrogen and sulfur content), proximate analysis (moisture, ash, volatile and fixed carbon (\% d.b.) of clean woodchip, switchgrass bio-char and red oak bark bio-char. Mineral 
composition in parts per million (ppm) of switchgrass bio-char and red oak bark bio-char.

Table 3.2 Percent char and bio-oil yields (mean $\pm \mathrm{SD}$, replications $=2$ ) produced from pyrolysis of clean woodchip at $500^{\circ} \mathrm{C}$ followed by catalytic upgrading of pyrolysis vapors using bio-char catalysts made from switchgrass and red oak wood bark. The catalyst to woodchip ratio (by weight) was kept

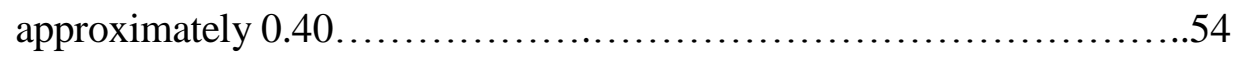

Table 3.3 Percent char and bio-oil yields (mean $\pm \mathrm{SD}$, replication=2) produced from pyrolysis of clean woodchip at $500^{\circ} \mathrm{C}$ followed by catalytic upgrading of pyrolysis vapors using bio-char catalysts made from switchgrass with different catalyst to woodchip ratio (by weight) as 0.1 and 0.4 . .57

Table 3.4 Percent of gas compositions (mean $\pm \mathrm{SD}$, replication=2) produced during vapor upgrading pyrolysis of clean woodchip at $300^{\circ} \mathrm{C}, 400^{\circ} \mathrm{C}$ and $500^{\circ} \mathrm{C}$ followed by catalytic upgrading of pyrolysis vapors using bio-char catalysts made from red oak bark and switchgrass loaded as catalyst to

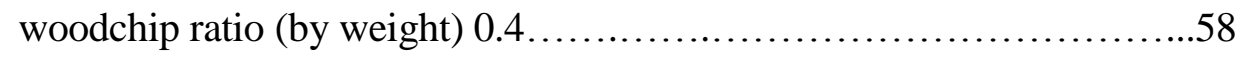

Table 3.5 $\mathrm{pH}$ and percentage moisture content (mean $\pm \mathrm{SD}$, replication $=2)$ in the biooil produced from woodchip pyrolysis at $500^{\circ} \mathrm{C}$ followed by catalytic upgrading of pyrolysis vapors using bio-char catalysts made from switchgrass and red oak wood bark. The catalyst to woodchip ratio (by

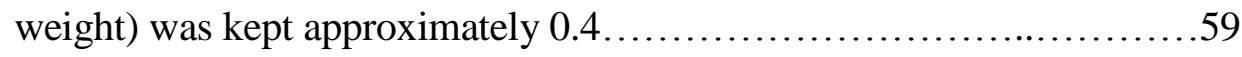

Table 3.6 Calorific value (HHV) and elemental composition (CHNS) of raw, Chars 
and bio-oils produced from woodchip with and without using switchgrass and red oak bark bio-chars as pyrolysis vapor upgrading catalysts at catalyst to biomass ratio loading of 0.4 at dry basis...................61

Table 3.7 Energy and carbon distribution of bio-char and bio-oil yield from clean wood chips, and using switchgrass and red oak bark bio-chars as pyrolysis vapor upgrading catalyst at dry basis ( catalyst to biomass ratio of 0.4) .62 


\section{CHA P T E R 1: I N TR O D U C T I O N}

Lignocellulose biomass, such as wood, is one of the main renewable energy resources. Biomass is different from other renewable energy resources as it is the only one that can produces liquid, solid and gaseous fuels when processed through appropriate methods. The processing methods of biomass can be divided into biological (anaerobic digestion and fermentation) and thermal pathways. Thermal pathways are direct combustion, gasification and fast pyrolysis. Combustion can provide the heat and steam for later electricity generation. In addition, gasification of biomass can provide a fuel gas for combustion, electricity generation, and liquid fuel production indirectly via Fisher-Tropsch process. Fast pyrolysis is the only thermochemical method that can directly produce liquid fuel, which can substitute for fuel oil to be used for heating or electricity generation. As liquid fuel is more convenient for transportation and storage, currently more study is focusing on the fast pyrolysis (U.S. Energy Information Administration, 2012).

\subsection{Pyrolysis Process}

Pyrolysis reactions take place in an inert atmosphere at elevated temperatures. The processing temperature of fast pyrolysis ranges from $400{ }^{\circ} \mathrm{C}$ to $650{ }^{\circ} \mathrm{C}$ (Mohan et al., 2006). During pyrolysis, heat transfers from the heat source to the biomass feedstock raising its temperature well above the decomposition temperature of biomass polymers (cellulose, hemicellulose, lignin, etc.). Most fast pyrolysis processes are followed by catalytic upgrading of pyrolysis vapors. Kinetics and thermal decomposition mechanisms for the pyrolysis of plant biomass and its constituents have been studied extensively. Recently, more studies have focused on the use of catalysts for biomass cracking (in-situ upgrading and ex-situ upgrading) to generate chemicals (Mohan et al., 2006). Two main products are 
produced during this process, condensable vapors and solid products. The condensable vapors are cooled to form a dark brown liquid, mostly referred to as bio-oil. The bio-oil yield has been reported as high as $80 \%$ of the weight of the dry biomass. The solid product is called bio-char or char and non-condensable vapors are called gaseous products (Bridgwater and Peacocke, 2000).

Pyrolysis is difficult to precisely define, especially when applied to biomass. Old literature generally equates pyrolysis to carbonization, in which the principal product is a solid char. However, now pyrolysis is defined as the processes in which bio-oils are preferred products.

The general mechanisms that occur during pyrolysis are described by Czernik et al. (1994). The mechanism involves transfer of heat from a heat source to the inner matrix of biomass followed by series of complex pyrolysis reactions at places where the temperature reaches critical pyrolysis temperature. The pyrolysis reactions lead to release of volatiles and formation of char. The volatiles are removed through carrier gas away from the reaction zones and through macro pores of the char. Some volatiles may deposit back on relatively colder biomass surfaces leading to secondary cracking reactions. The thermal cracking includes further thermal decomposition, reforming, water-gas shift reaction, radical recombination, and dehydration, which are a function of the process's residence time, temperature, and pressure profile.

\subsection{Anatomy of Biomass}

The properties of pyrolysis products generally depend on the type of wood, either hardwood or softwood, or biomass used. Generally, "hardwood" is a rather imprecise term identifying the broad class of angiosperm trees. "Softwood" identifies the class of 
gymnosperm trees. The terms hardwood and softwood can be misleading because they have little relation to the wood hardness. Generally speaking, the microscopic cellular structure in softwood and hardwood is different. Hardwood contains longitudinal wood fibers, which provide strength and vessel elements, and conduct sap. However, softwood has only one type of cells called tracheid, which serves both purposes. The major chemical polymers of woody biomass are cellulose (40-50\%), hemicellulose (25-35\%) and lignin (18-35\%) polymers (Rowell, 1984). All these chemical polymers simultaneously decompose during pyrolysis. In this case, biomass pyrolysis products are a complex combination of the products from the pyrolysis of individual polymer: cellulose, hemicellulose, lignin and extractives. Cellulose fibers provide wood its strength and comprise $40-50$ wt. $\%$ of dry wood. Cellulose is a high molecular-weight $\left(10^{6}\right.$ or more) linear polymer (Figure 1.1). The basic repeating unit of the cellulose polymer consists of two glucose anhydride units, called a cellobiose unit (Rowell, 1984).

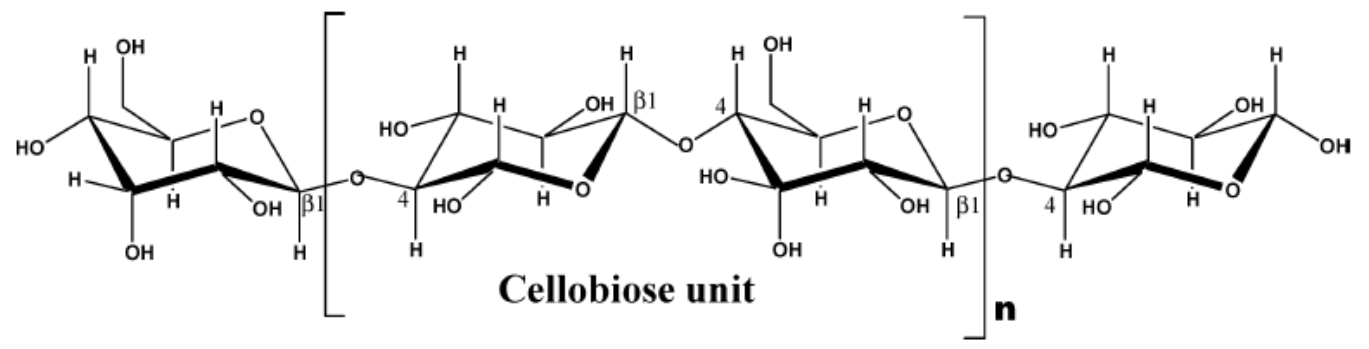

Figure 1.1. Chemical structure of cellulose (Rowell, 1984).

The degradation of cellulose occurs between $240-350{ }^{\circ} \mathrm{C}$. Hydrocellulose and levoglucosan are produced during the degradation reaction (Cooper, 1944; Van Hove, 1956). Tang and Neill (1964) observed that cellulose degradation were completed at $360^{\circ} \mathrm{C}$ at the 
heating rate $12{ }^{\circ} \mathrm{C} / \mathrm{min}$ under an atmosphere of helium. They also observed an exothermic nature of the decomposition reaction at $335^{\circ} \mathrm{C}$ (Tang and Neill, 1964).

Hemicellulose usually accounts for $25 \%-35 \%$ of the mass of dry wood. It is the second major chemical constituent in wood. However, its content varies from one wood species to another. Generally, hemicellulose content is $28 \%$ in softwoods, and $35 \%$ in hardwoods (Rowell, 1984). Hemicellulose is a mixture of various polymerized monosaccharides, including glucose, mannose, galactose, xylose, arabinose, 4-O-methyl glucuronic acid and galacturonic acid residues (Figure 1.2) (Egüés et al., 2013). Hardwood hemicelluloses are rich in xylan and contain small amounts of glucomannan. In addition, softwood hemicelluloses contain a small amount of xylan but are rich in galactoglucomannan (Han et al. 2013).

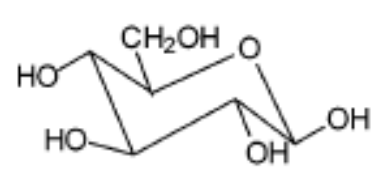

Glucose

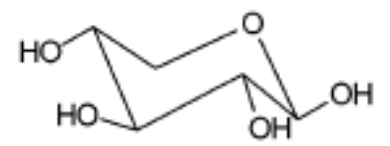

Xilose
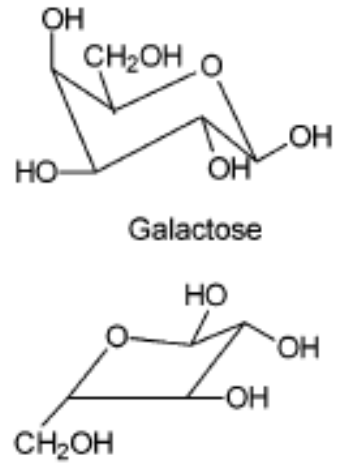

Arabinose
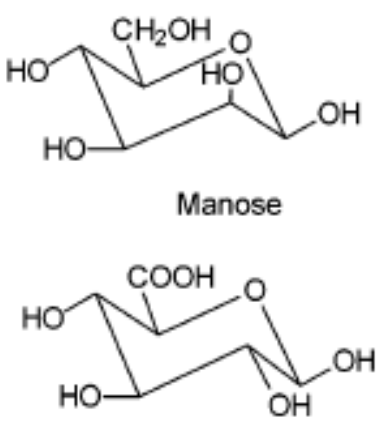

Glucuronic acid

Figure 1.2. Main types of hemicellulose (Mohan et al., 2006)

The degradation of hemicellulose takes place in the temperatures range of 200$260{ }^{\circ} \mathrm{C}$. Hemicellulose pyrolysis produces more volatiles, less tars, and less chars than cellulose pyrolysis. Most hemicelluloses do not yield significant amounts of levoglucosan. 
Lignin is the third major polymer of wood, which accounts for $25 \%-35 \%$ of the weight of softwoods and 16\%-25\% of the weight of hardwoods (Rowell, 1984). Lignin acts as a binder for the agglomeration of fibrous cellulosic components. Also, it protects cellulosic fibers from rapid microbial and fungal destruction. Lignin is a three-dimensional, amorphous, highly branched, polyphenolic unit (Figure 1.3) (Joseph and Aminul, 1999). Lignin mainly decomposes in a temperature range of 280 to $500{ }^{\circ} \mathrm{C}$. The main products of lignin pyrolysis are phenols. Lignin is more difficult to degrade than cellulose or hemicelluloses. In addition, lignin pyrolysis produces more residual char than does the pyrolysis of cellulose (Zhang et al., 2012b).

\subsection{Pyrolysis Products}

Bio-oil is combination of pyrolysis products of cellulose, hemicellulose, and lignin polymers. Bio-oil from fast pyrolysis has several environmental advantages over fossil fuels (Mohan et al., 2006). First of all, bio-oils may be considered carbon neutral, but this is still under debate. In this case, they may generate carbon dioxide credits. Also, woody biomass contains insignificant amounts of sulfur. Therefore, no $\mathrm{SO}_{\mathrm{x}}$ emissions are generated. Bio-oil fuels also generate more than $50 \%$ lower $\mathrm{NO}_{\mathrm{x}}$ emissions than traditional fossil fuel. Therefore, bio-fuels are cleaner and cause less pollution (Pütün, 2002). 


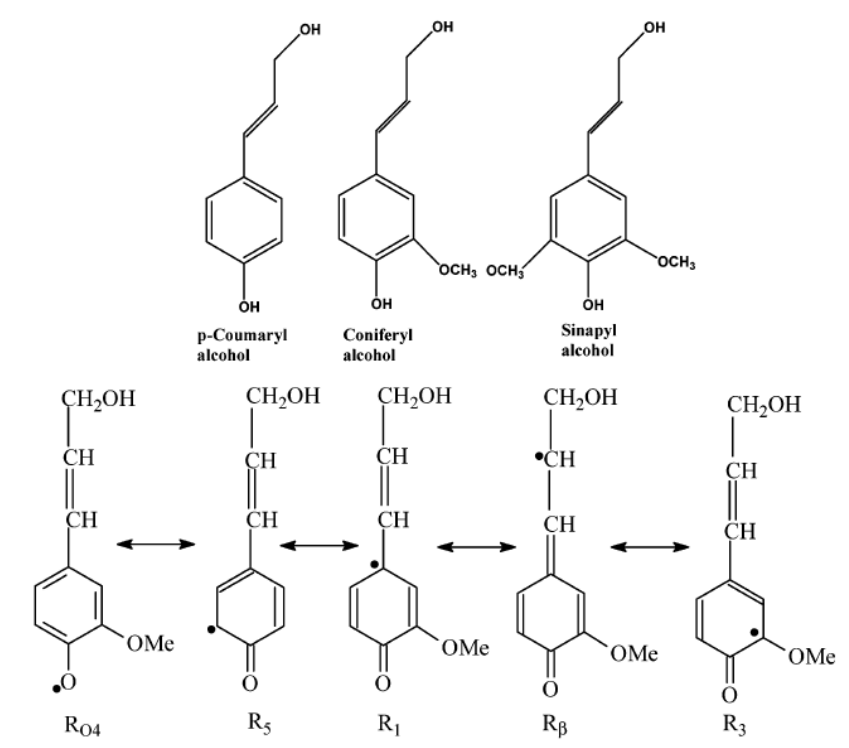

Figure 1.3. p-Coumaryl, coniferyl, and sinapyl structures and resonance hybrid structures of phenoxy radicals produced by the oxidation of coniferyl (Mohan et al., 2006)

The yield of bio-oils from wood and other biomass is in the range of $60-95$ wt. \% (Bridgwater, 1996). The appearance of bio-oil is almost black or dark red-brown to dark green, depending on the initial feedstock and the mode of fast pyrolysis. The bio-oil has varying quantities of water content, ranging from 30 to $50 \mathrm{wt}$. \%, depending on the production and collection method. In addition, bio-oil cannot be dissolved in water. The biooil density is higher $(1.2 \mathrm{~kg} / \mathrm{L})$ than light fuel oils $(0.85 \mathrm{~kg} / \mathrm{L})($ Bridgwater and Peacocke, 2000). The viscosity of bio-oil varies from as low as $25 \mathrm{cSt}$ to as high as $1000 \mathrm{cSt}$ (measured at $40{ }^{\circ} \mathrm{C}$ ) depending on the feedstock, the water content of the oil, the pyrolysis process used, and the extent to which the oil has been aged. The aging of bio-oil causes an increase in viscosity and a decrease in volatility, phase separation, and change in deposition of gums with time (Bridgwater and Peacocke, 2000). Bio-oil can serve as a substitute for fuel oil or diesel in many static applications, including boilers, furnaces, engines, and turbines for electricity generation (Shihadeh and Hochgreb, 2000). A surface-active bio-oil solution, that 
was prepared from vacuum pyrolysis bio-oil with a phenol-to-levoglucosan mass ratio of 4.8, was used as a foaming agent in the flotation of sulfured copper (Bridgwater, 1996).

\subsection{Catalytic Pyrolysis}

Bio-oil from the pyrolysis process needs further refining before it can be directly used as gasoline. In principle, bio-oil is refined using petroleum refining technology, which has two stages in processing: hydrotreating and hydrocracking. Butane or lighter components, stable hydrogenated oils, and a heavy fraction (boiling point $>350{ }^{\circ} \mathrm{C}$ ) are formed during the first stage of hydrotreatment (Jones, 2009). The hydrogenated oils formed in first stage are separated from the other fractions by distillation, and the remaining heavy fraction is hydrocracked into light hydrocarbon diesel fuels in the second stage. The resulting hydrogenated oils are stable enough to be used as gasoline, with a much higherenergy content $(\mathrm{HHV}=46 \mathrm{MJ} / \mathrm{kg}$ ) (Jones et al., 2009). In petroleum-refining processes, Fluid Catalytic Cracking (FCC) catalysts, hydrocracking catalysts, and hydrotreating catalysts are employed (Gerber, 1999). During the pyrolysis process, the catalysts transform heavy crude oil into light high-quality oil fractions. However, the two-stage process suffers from catalyst life and performance. The performance properties of industrial catalysts (FCC, ZSM-5 and mental oxidized ZSM-5) are shown in Table 1.1. A literature review shows that all FCC and ZSM catalysts prefer to gasify products produced from cellulose and hemicellulose pyrolysis than products produced from lignin. It is well documented that using the above catalysts decreases net carbon yield and increases moisture content of biooil (French and Czernik, 2010). 
Table 1.1 Performance of petroleum industry catalysts (FCC, ZSM-5 and mental oxidized

ZSM-5).

\begin{tabular}{|c|c|c|c|}
\hline Catalyst & Structure & $\begin{array}{l}\text { Functions in petroleum } \\
\text { industry }\end{array}$ & $\begin{array}{l}\text { Drawbacks when used as woody } \\
\text { biomass pyrolysis catalyst }\end{array}$ \\
\hline $\begin{array}{l}\text { Fluid } \\
\text { Catalytic } \\
\text { Cracking }\end{array}$ & $\begin{array}{l}\text { Made up of finely } \\
\text { divided }(\sim 1-5 \quad \mu \mathrm{m}) \\
\text { lanthanide- } 89 \text { substituted } \\
\text { X-or Y-type zeolite } \\
\text { imbedded in amorphous } \\
\text { silica-alumina particles } \\
(\sim 50 \mu \mathrm{m}) .\end{array}$ & $\begin{array}{l}\text { Increase yield of gasoline } \\
\text { from heavy gas oils, } \\
\text { naphtha, and some } \\
\text { residual oil. }\end{array}$ & $\begin{array}{l}\text { Deactivates very quickly due to coke } \\
\text { deposition and requires constant } \\
\text { regeneration. } \\
\text { Metals in feedstock poison FCC } \\
\text { catalysts. } \\
\text { Less bio-oil yield, increased coke and } \\
\text { gas yields(Zhang et al., 2012a). }\end{array}$ \\
\hline ZSM-5 & $\begin{array}{l}\text { contains a microporous } \\
\text { crystalline structure } \\
\text { containing oxides of } \mathrm{Si} \\
\text { and } \mathrm{Al} \text { (Derouane et al, } \\
\text { 1981) in form of } \mathrm{AlO}_{4} \\
\text { and } \mathrm{SiO}_{4}\end{array}$ & $\begin{array}{l}\text { Formation } \mathrm{Si}-\mathrm{OH} \text { groups } \\
\text { at the catalyst surface at } \\
600^{\circ} \mathrm{C} \text { can provide } \\
\text { reactive acid-base sites to } \\
\text { catalyst. }\end{array}$ & $\begin{array}{l}\text { Coke formed at acid-base sites leads to } \\
\text { deactivation of these sites. } \\
\text { Less acid and alcohols, and more } \\
\text { ketones formed during the pyrolysis } \\
\text { process (Aho et al., 2008) } \\
\text { Low bio-oil yield and less average } \\
\text { molecular weight obtained (Williams } \\
\text { and Nugranad, 2000). } \\
\text { Increased moisture content in bio-oil } \\
\text { from } 5.4 \% \text { to } 16.7 \% \text { (Aho et al. 2008) }\end{array}$ \\
\hline $\begin{array}{l}\text { Metal-oxide } \\
\text { ZSM-5 }\end{array}$ & $\begin{array}{l}\text { Metal oxide species } \\
(\mathrm{MOx}) \text { are impregnated } \\
\text { on the porous structure } \\
\text { of the ZSM-5 (Lee and } \\
\text { Wachs, 2008) }\end{array}$ & $\begin{array}{l}\text { Metal oxides attach } \\
\text { themselves to the acid } \\
\text { sites of the zeolite surface } \\
\text { and form double -bonded } \\
\text { oxygen function groups. } \\
\text { The heavy organic } \\
\text { compounds first interact } \\
\text { with alumina site and } \\
\text { create unstable organic } \\
\text { radicals (Lee and Wachs, } \\
\text { 2008). }\end{array}$ & $\begin{array}{l}\text { Ni loaded ZSM-5 leads to the formation } \\
\text { of toluene (French and Czernik, 2010). }\end{array}$ \\
\hline
\end{tabular}

A solution to reducing negative effects of petroleum refining catalysts would be to use bio-char catalysts. Bio-chars are not being used as a catalyst during the pyrolysis process. However, it has a highly porous structure with great surface area and sorption properties, comparable silica-to-alumina ratio, making bio-chars potential catalysts for the pyrolysis process. Two main approaches have been adopted to incorporate catalysts during pyrolysis. The first approach is to mix the catalyst with the feedstock during pyrolysis; the other approach is to perform vapor upgrading using catalysts before the products are condensed. 


\subsection{Objectives}

Therefore, this study is aimed at conducting pyrolysis kinetics of wood polymers and exploring the use of bio-char as a potential catalyst for pyrolysis vapor refining. The objectives of this study were follows:

1. To document the thermo-chemical decomposition behavior of hardwood's physical components and to model the decomposition of wood polymers (cellulose, hemicellulose (xylan) and lignin polymers) using thermo-gravimetric analysis and the isoconversion method.

2. To compare the influence of bio-char catalysis on ex-situ pyrolysis vapor upgrading during woodchip pyrolysis.

This study first explores the pyrolysis kinetics of different wood polymers (cellulose, hemicellulose and lignin) and wood physical components (bark, sapwood and heartwood). Additionally, switchgrass bio-char and red oak bark bio-char are used as the catalyst during vapor upgrading of pyrolysis products.

\section{References}

Aho, A., N. Kumar, K. Eränen, T. Salmi, M. Hupa, and D. Y. Murzin. 2008. Catalytic pyrolysis of woody biomass in a fluidized bed reactor: Influence of the zeolite structure. Fuel 87(12):2493-2501.

Bridgwater, A. V. 1996. Production of high grade fuels and chemicals from catalytic pyrolysis of biomass. Catalysis Today 29(1-4):285-295.

Bridgwater, A. V., and G. V. C. Peacocke. 2000. Fast pyrolysis processes for biomass. Renewable and Sustainable Energy Reviews 4(1):1-73.

Cooper, C. L. 1944. Smaller Foraminifera from the Porters Creek formation (Paleocene) of Illinois. Report of Investigations No. 98, Urbana, Illinois.

Czernik, S., D. K. Johnson, and S. Black. 1994. Stability of wood fast pyrolysis oil. Biomass and Bioenergy 7(1-6):187-192. 
Egüés, I., A. Eceiza, and J. Labidi. 2013. Effect of different hemicelluloses characteristics on film forming properties. Industrial Crops and Products 47:331-338.

French, R., and S. Czernik. 2010. Catalytic pyrolysis of biomass for biofuels production. Fuel Processing Technology 91(1):25-32.

Gerber, M. A., J. G. Fyre, L. E. Bowman, J. L. Fulton, L. J. Silva, and C. M. Wai. 1999. Regeneration of hydrotreating 275 and FCC catalysts. N. N. Laboratory, ed. Richland WA.

Han, S.H., D. H. Cho, Y. H. Kim, and S. J. Shin. 2013. Biobutanol production from 2-yearold willow biomass by acid hydrolysis and acetone-butanol-ethanol fermentation. Energy 61:13-17.

U.S. Energy Information Administration. Annual energy outlook 2012, Web. 21 June 2013.

Jones, S. B., J. E. Holladay, C. Valkenburg, D. J. Stevens, C. W. Walton, C. Kinchin, D. C. Elliott, and S. Czernik. 2009. Production of gasoline and diesel from biomass via fast pyrolysis, hydrotreating and hydrocracking: A Design Case. P. N. N. Laboratory, ed.

Joseph, L. M., and I. Aminul. 1999. Lignin chemistry, technology, and utilization: A brief history. In Lignin: Historical, Biological, and Materials Perspectives, 2-99. American Chemical Society.

Lee, E. L., and I. E. Wachs. 2008. Surface chemistry and reactivity of well-defined multilayered supported M1Ox/M2Ox/SiO2 catalysts. Journal of Catalysis 258(1):103-110.

Mohan, D., C. U. Pittman, and P. H. Steele. 2006. Pyrolysis of wood/biomass for bio-oil: a critical review. Energy \& Fuels 20(3):848-889.

Pütün, A. E. 2002. Biomass to bio-oil via fast pyrolysis of cotton straw and stalk. Energy Sources 24(3):275-285.

Ren, J. L., R. C. Sun, C. F. Liu, Z. Y. Chao, and W. Luo. 2006. Two-step preparation and thermal characterization of cationic 2-hydroxypropyltrimethylammonium chloride hemicellulose polymers from sugarcane bagasse. Polymer Degradation and Stability 91(11):2579-2587.

Rowell, R. M. 1984. The chemistry of solid wood. In The Chemistry of Solid Wood, i-v. M. J. Comstock, ed: American Chemical Society.

Shihadeh, A., and S. Hochgreb. 2000. Diesel engine combustion of biomass pyrolysis oils. Energy \& Fuels 14(2):260-274.

Sjöström, E. 1993. Wood chemistry :fundamentals and applications. In San Diego :Academic Press. 
Tang, W. K., and W. K. Neill. 1964. Effect of flame retardants on pyrolysis and combustion of $\alpha$-cellulose. Journal of Polymer Science Part C: Polymer Symposia 6(1):6581.

Van Hove, L. 1956. Energy corrections and persistent perturbation effects in continuous spectra: II. The perturbed stationary states. Physica 22(1-5):343-354.

Williams, P. T., and N. Nugranad. 2000. Comparison of products from the pyrolysis and catalytic pyrolysis of rice husks. Energy 25(6):493-513.

Zhang, H., T. R. Carlson, R. Xiao, and G. W. Huber. 2012a. Catalytic fast pyrolysis of wood and alcohol mixtures in a fluidized bed reactor. Green Chemistry 14(1):98-110.

Zhang, M., F. L. P. Resende, A. Moutsoglou, and D. E. Raynie. 2012b. Pyrolysis of lignin extracted from prairie cordgrass, aspen, and Kraft lignin by Py-GC/MS and TGA/FTIR. Journal of Analytical and Applied Pyrolysis 98(0):65-71. 
CHA P T ER 2: P Y R OLYS IS K INET ICS OF PHYSICA L COMPONENTS OF WOOD A N D W OOD-POLYMERS US ING ISOCONVER S I N METHO D

\subsection{Introduction}

Renewable energy is currently attracting worldwide interest, as it is partly the solution to environmental concerns arising from the overuse of fossil fuels. Consumption of traditional fossil fuels releases carbon stored beneath the earth's crust for millennia into the atmosphere in the form of greenhouse gases (GHG) which are responsible for global warming. On the other hand, biomass when burned as fuel releases carbon previously sequestered from the atmosphere, thereby, theoretically not increasing GHG levels. The GHG emissions during the combustion of biomass are assumed to be the same as that absorbed through the photosynthesis process during biomass growth (Demirbas, 2005), especially in the case of forest and agricultural biomass (Biagini et al., 2006). However, an overall life cycle analysis has shown an increase in GHG emissions for biomass utilization for biofuels (International, 2009). The increased GHG emissions are the result of the use of fossil energy during various operations involved in supply-chain logistics, for example, harvesting, transport, preprocessing, and inefficient conversion technologies (Nitschke and Innes, 2008). On the other hand Sharma et al. (Sharma and Rowe, 1992) reported that biomass collection from prolonged sustainably managed forests actually reduces net GHG emissions, thereby, making it carbon negative. In the United States, the total primary energy consumption from various biomass resources is currently $4 \%$, and it is expected to increase to $10 \%$ by the year 2035 (EIA, 2012). Most of the biomass utilization for bioenergy accounts for generation of electricity, heat and liquid transportation fuels. Among this biomass feedstock, roughly, more than $50 \%$ is in the form of woody biomass (Stokes, 
2011). The current contribution of woody biomass is 130 million dry tons, and it is expected reach to 210 and 225 million dry tons by 2022 and 2030, respectively (Stokes, 2011). Woody biomass is mainly used for electricity production, heating homes and providing process heat for industrial facilities through three primary thermal-conversion methodscombustion, gasification and pyrolysis (Balat, 2006; Demirbaş, 2001; McKendry, 2002; Panwar et al., 2012). The process air requirements vary for these three thermal-conversion methods. For combustion, gasification and pyrolysis the air consumption is excess, partial and nonexistent, respectively (Balat et al., 2009).

Pyrolysis is inherently present in combustion and gasification processes. It is an outstanding conversion method as it can directly generate solid, liquid and gaseous products under anoxic conditions (Balat et al., 2009). The wood polymers (cellulose, hemicellulose and lignin) present in any biomass and the pyrolytic conditions are the primary factors that control pyrolysis reactions and resulting products (Raveendran et al., 1996). Any typical woody biomass contains $40-50 \%$ cellulose, $25-35 \%$ hemicellulose and 10\%-40\% lignin (Mohan et al., 2006; Yaman, 2004). In addition, the pyrolytic conditions including pyrolysis temperature, pyrolysis pressure, vapor-phase residence time and heating rate affect the chemical reactions responsible for producing various chemical compounds present in biooils (Antal, 2004).

Wood polymers of woody biomass (cellulose, hemicellulose and lignin) interact during pyrolysis. In the temperature range of $150{ }^{\circ} \mathrm{C}$ to $180{ }^{\circ} \mathrm{C}$, the stability of cellulose is reduced (Beall and Eickner, 1970). Furthermore, residual cellulose is protected by lignin after the temperature reaches $300{ }^{\circ} \mathrm{C}$ (Beall and Eickner, 1970). In previous studies data on weight loss as a function of temperature was generated from TGA (Thermogravimetric 
analysis) equipment to study pyrolysis kinetics of woody biomass (Gaur, 1998). Different experimental methods and mathematical models have been used to carry out the TGA experiments. For example, the isothermal method uses constant temperatures while nonisothermal heating ramps the temperature from ambient to the target temperature at a given heating rate. The data generated from TGA include temperature, time and weight changes during the pyrolysis process and these data can be used to calculate the activation energies of different pyrolysis phases (Mohan et al., 2006) using a variety of mathematical models.

Activation energy, a quantified factor of pyrolysis kinetics has been studied by several different mathematical methods (Gaur, 1998). Gaur and Reed (Gaur, 1998) have documented the following methods for TGA data processing: Coat and Redfern method1964; Gyulai and Greenhow method-1974; Doyle's method-1961; Zsako method-1973; Satava and Skvara method-1969; Freeman and Carroll method-1958; Ingraham and Marrier method; Vachuska and Voboril method; Varhegyi’s Integral Solution-1978; and Gaur and Reed method-1994.

While determination of pyrolysis kinetics is critical to the understanding of the pyrolysis process for a given biomass, only a handful of studies have reported hardwood kinetics (Herrera et al., 1986; Slopiecka et al., 2012). However, no study has documented the effects of physical components (sapwood, heartwood and bark) during the pyrolysis process. The wood polymers in sapwood, heartwood and lignin are expected to be different and, in this case, may lead to different pyrolysis results.

This paper presents the thermo-chemical decomposition behavior of hardwood's physical components and model wood-polymers-cellulose, hemicellulose (xylan) and lignin polymers - using thermo-gravimetric analysis and the isoconversion method. The use 
of the isoconversion method has been successfully documented for pyrolysis kinetics (Kim et al., 2005; Kim and Kim, 2004). It was hypothesized that pyrolysis kinetics of sapwood, heartwood, and bark will be different and that the isoconversion method will be valid for estimation of Arrhenius parameters for all fractional conversion values.

\subsection{Experiment Procedures}

Fresh samples of yellow-poplar and red oak were collected from the West Virginia University (WVU) Research Forest. The samples were separated into twelve subsamples of bark, sapwood and heartwood (Figure 2.1). The physical components (bark, sapwood and heartwood) were ground to less than $1 \mathrm{~mm}$ particle size using a mill (Model: ED5, Thomas, Chillicothe, MO), and subsequently oven dried for 24 hours at $103{ }^{\circ} \mathrm{C}$. In addition, pure cellulose (9004-34-6, Fisher, Hanover Park, IL), xylan (58-86-6, TCI, Portland, OR) and lignin (Indulin AT, Meadwestvaco, Charlston, SC) were obtained from commercial venders as representative of wood-polymers. All samples were analyzed for the cell-wall specific gravity, calorific value, ultimate analysis (carbon, hydrogen, nitrogen, and sulfur content), proximate analysis (fixed carbon, volatile matter, and ash content) and thermo-chemical decomposition behavior. In addition, the wood samples were tested for mineral composition and chemical composition by the Agricultural and Environmental Sciences Laboratory, University of Georgia.

Specific gravity (true grind density) was measured according to ASAE Standard S269.4 using a Multipycnometer (Model: Manual Multipycnometer, Quantachrome, FL). Calorific value was measured using a bomb calorimeter (Model: 6300 Calorimeter, Parr Instrument Company, IL) according to the ASTM D5865 standard without accounting for 
heat of reactions for nitric and sulfuric acids. Ultimate analysis was performed using a CHNS analysis (Model: Series II CNHS/O Analyzer 2400, PerkinElmer, Waltham, MA). Proximate analysis (moisture, volatile matter, fixed carbon and ash) was carried out using a proximate analyzer (Model: LECO 701, LECO Corporation, St. Joseph, MI) following the ASTM D3174 standard. Mineral composition, Acid Detergent Fiber (ADF), Neutral Detergent Fiber (NDF), and Acid Detergent Lignin (ADL) were measured at the University of Georgia Agricultural and Environmental Sciences Lab, Athens (UGA-AESL), GA. Data on fiber analysis and ash content were used to determine cellulose, hemicellulose, and lignin content according to following equations:

$$
\begin{aligned}
& \% \text { Hemicellulose }=\% \mathrm{NDF}-\% \mathrm{ADF} \\
& \% \text { Cellulose }=\% \mathrm{ADF}-(\% \text { Lignin }+\% \text { Ash }) .
\end{aligned}
$$

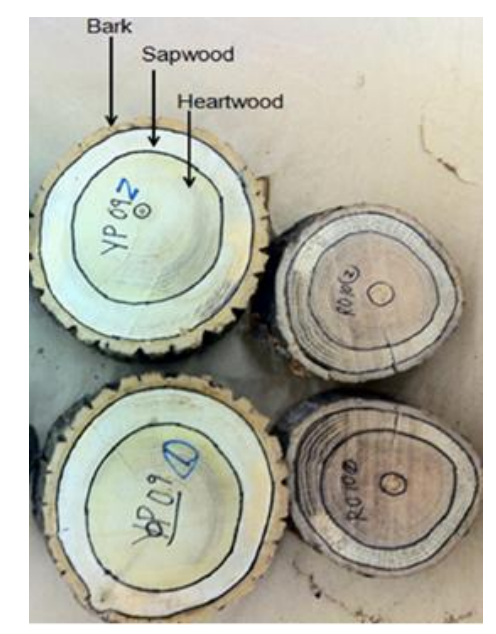

Figure 2.1. Yellow-poplar and red oak samples showing bark, sapwood and heartwood.

Thermo-chemical decomposition behavior was assessed using a thermogravimetric analyzer (TGA) (Model: Q50, TA Instruments, Schaumburg, IL). The TGA 
experiments were performed by heating a 8-12 mg sample from $50{ }^{\circ} \mathrm{C}$ to $700{ }^{\circ} \mathrm{C}$ at three heating rates of $10{ }^{\circ} \mathrm{C}, 30{ }^{\circ} \mathrm{C}$, and $50{ }^{\circ} \mathrm{C} / \mathrm{min}$ under a nitrogen flow of $50 \mathrm{~cm}^{3} / \mathrm{min}$. Data obtained from thermo-gravimetric analysis were analyzed for any changes in thermochemical decomposition behavior. The TGA data were analyzed to determine the Arrhenius activation energy (E) and pre-exponential constant (A) using the isoconversion method described by Kim et al. (Kim and Agblevor, 2007). In this method, the rate of fractional weight loss, $d X / d t$, is expressed as a function of conversion $f(X)=(1-X)^{n}$, where $X$ is fractional conversion ( $\left.\frac{\text { initial weight-current weight }}{\text { initial weight-final weight }}\right)$ and ' $n$ ' is the order of the reaction:

$$
\frac{d X}{d t}=k \cdot(1-X)^{n}
$$

The reaction rate constant (k) was substituted by the following Arrhenius expression:

$k=A \cdot \exp (-E / R T)$

Where $\mathrm{R}$ is universal gas constant and $\mathrm{T}$ is the absolute temperature in $\mathrm{K}$. Upon substituting equation (2) into equation (1) and taking the natural logarithm, equation (1) is transformed into the following equation:

$$
\ln \left(\frac{d X}{d t}\right)=\ln A+n \ln (1-X)-\frac{E}{R T}
$$

The activation energy (E) in equation (3) was determined from the relationship between $\ln (\mathrm{dX} / \mathrm{dt})$ and $(1 / \mathrm{T})$ for fractional weight loss $(\mathrm{X})$. Consequently, a family of graphical curves was obtained for a series of $X(0.01,0.02 \ldots, 0.9)$ values of fractional 
conversion. For example, the corresponding temperatures at 0.5 conversion of the cellulose samples were $608.15,622.15$, and $628.15 \mathrm{~K}$, respectively, for the heating rates 10,30 , and $50{ }^{\circ} \mathrm{C} / \mathrm{min}$. The values of $\ln (\mathrm{dX} / \mathrm{dt})$ were: $-1.3451,-0.41228$, and -0.09330 , with corresponding $1 / \mathrm{T}$ values of $1.644331 \times 10^{-3}, 1.607329 \times 10^{-3}, 1.591976 \times 10^{-3}\left(\mathrm{~K}^{-1}\right)$. The intercept $\left(\ln \left(\mathrm{A}(1-\mathrm{X})^{\mathrm{n}}\right)\right.$ was calculated from the linear relationship for the corresponding conversions assuming the order of reaction to be either 0 or 1 .

\subsection{Results and Discussion}

\subsubsection{Feedstock Characterization}

Thermogravimetric Analysis

Physical and chemical properties including calorific value, cell wall specific gravity, ultimate analysis, proximate analysis, mineral analysis of woody biomass physical components (bark, sapwood and heartwood) and wood polymers (cellulose, xylan and lignin) were determined as references for further analysis. Table 2.1 shows the results of cell-wall specific gravity and calorific values for all samples. As shown in Table 2.1, there are no significant differences among the cell-wall specific gravity of bark, sapwood and heartwood samples of red oak and yellow-poplar ( $\mathrm{p}$-value>0.05). Similar results were observed for the calorific value data which were consistent with Corder's findings (Corder, 1976). Adebayo et al. (Adebayo et al., 2009) had measured specific gravity of wooden blocks of size $10 \times 10 \times 40 \mathrm{~mm}$ of sapwood and heartwood of red oak and yellow-poplar samples. The reported average overall specific gravity of sapwood and heartwood logs (not of cell-wall) were 0.46 and 0.46 for red oak, and 0.58 and 0.61 for yellow-poplar, respectively (Adebayo et al., 2009). The cell-wall specific gravity, reported in this paper, is 
always greater than that of wood because it does not account for pores present. The result was in agreement with a previous study (Vincent, 1999). The difference between the overall specific gravity and cell-wall specific gravity is related to the porosity of the wood matrix. Porosity directly affects heat transfer and mass transfer during biomass pyrolysis (Miller and Bellan, 1996). Miller and Bellan (1996) have reported that high initial porosity reduced heat transfer rates during pyrolysis. However, given small sample size (10-12mg) in the present thermogravimetric experiments, it is unlikely that heat and mass transfer limitation effects would be observed.

Table 2.1. Calorific value and cell wall specific gravity measurements (mean \pm standard deviation, 2 replications, 2 measurements on each replication) for samples of yellow-poplar and red oak's components (bark, sapwood and heartwood) and wood-polymers.

\begin{tabular}{llll}
\hline Property & & $\begin{array}{l}\text { Calorific value } \\
(\mathrm{MJ} / \mathrm{Kg})\end{array}$ & Cell wall specific gravity \\
\hline Red oak & Bark & $18.86 \pm 0.44$ & $1.69 \pm 0.07$ \\
& Sapwood & $18.78 \pm 0.51$ & $1.85 \pm 0.18$ \\
& Heartwood & $18.38 \pm 0.36$ & $1.79 \pm 0.12$ \\
\hline Yellow-poplar & Bark & $19.54 \pm 1.02$ & $1.74 \pm 0.16$ \\
& Sapwood & $18.81 \pm 0.88$ & $1.85 \pm 0.14$ \\
& Heartwood & $18.65 \pm 0.86$ & $1.92 \pm 0.25$ \\
\hline Wood polymers & Cellulose & $-*$ & 1.27 \\
& Xylan & $-*$ & 1.53 \\
& Lignin & $25.79 \pm 0.09$ & 1.25 \\
\hline
\end{tabular}

Table 2.2 shows the results of the ultimate analysis. No substantial differences were observed for carbon, hydrogen, and sulfur contents among bark, sapwood and heartwood. The average carbon content was 46-48\%, hydrogen content was $6 \%$, and sulfur content was $0.2 \%$. The nitrogen content was the highest for bark followed by sapwood and 
then heartwood. In addition, the carbon and sulfur content in the lignin polymer was significantly higher than in the cellulose and xylan polymers $(\mathrm{p}<0.05)$. The significantly higher sulfur content in the lignin polymer may be explained by the pulping and rough purifying process by which it was extracted. During one pulping process, superfluous sulfur compounds are used as chemical additives (Fengel and Wegener, 2003). Additionally, when looking at the molar ratio for cellulose, it had 1.78 mols of hydrogen and 0.89 mols of oxygen for each mol of carbon. Therefore, its molar formula may be written as $\mathrm{C}_{1} \mathrm{H}_{1.78} \mathrm{O}_{0.89}$, after ignoring nitrogen and sulfur. Similarly, molar formulae for xylan and lignin may be written as $\mathrm{C}_{1} \mathrm{H}_{1.99} \mathrm{O}_{0.97}$ and $\mathrm{C}_{1} \mathrm{H}_{1.14} \mathrm{O}_{0.33}$, respectively. Therefore, lignin contains the least amount of hydrogen and oxygen per mol of carbon. Similarly, molar formulae calculated for yellow-poplar sapwood, heartwood, and bark were $\mathrm{C}_{1} \mathrm{H}_{1.52} \mathrm{O}_{0.73}, \mathrm{C}_{1} \mathrm{H}_{1.50} \mathrm{O}_{0.72}$, and $\mathrm{C}_{1} \mathrm{H}_{1.48} \mathrm{O}_{0.67}$, respectively. Bark contains less oxygen and hydrogen than sapwood and heartwood and hence it should decompose at high temperatures producing more bio-char and phenolic rich bio-oil than the other two components.

Ultimate analysis is also directly related to the higher heating value of the material (Wright et al., 2010; Xu and Lad, 2007). The Dulong formula (HHV=0.338C+1.428(H$\mathrm{O} / 8)+0.095 \mathrm{~S}$ ) has been widely used for calculating higher heating values using $\mathrm{C}, \mathrm{H}$, and $\mathrm{O}$ content of biomass; however, the high ash content of biomass may limit the applicability of this formula. 
Table 2.2. Ultimate analysis (carbon, hydrogen, nitrogen and sulfur content) of bark, sapwood, and heartwood of red oak and yellow-poplar and wood-polymers (cellulose, xylan and lignin).

\begin{tabular}{llllll}
\hline Property & & Carbon (\%) & Hydrogen (\%) & Nitrogen (\%) & Sulfur (\%) \\
\hline Red oak & Bark & $47.52 \pm 1.44$ & $5.86 \pm 0.25$ & $0.56 \pm 0.00$ & $0.24 \pm 0.02$ \\
& Sapwood & $46.62 \pm 0.08$ & $5.89 \pm 0.01$ & $0.26 \pm 0.01$ & $0.18 \pm 0.04$ \\
& Heartwood & $46.97 \pm 0.21$ & $5.87 \pm 0.01$ & $0.07 \pm 0.01$ & $0.16 \pm 0.01$ \\
\hline Yellow-poplar & Bark & $48.16 \pm 0.50$ & $5.93 \pm 0.04$ & $0.76 \pm 0.02$ & $0.18 \pm 0.06$ \\
& Sapwood & $47.05 \pm 0.06$ & $5.96 \pm 0.01$ & $0.21 \pm 0.03$ & $0.21 \pm 0.01$ \\
& Heartwood & $47.53 \pm 0.30$ & $5.93 \pm 0.06$ & $0.13 \pm 0.01$ & $0.21 \pm 0.01$ \\
\hline Wood polymers & Cellulose & $42.00 \pm 0.04$ & $6.24 \pm 0.06$ & $0.99 \pm 0.07$ & $0.67 \pm 0.04$ \\
& Xylan & $40.14 \pm 0.42$ & $6.65 \pm 0.04$ & $0.51 \pm 0.09$ & $0.64 \pm 0.00$ \\
& Lignin & $61.68 \pm 0.01$ & $5.85 \pm 0.02$ & $1.29 \pm 0.10$ & $2.06 \pm 0.02$
\end{tabular}

Table 2.3 shows the results of the mineral composition of the physical components (sapwood, heartwood and bark) of red oak and yellow-poplar. The phosphorus, potassium, calcium, magnesium, manganese, aluminum, zinc compositions in bark were higher than in sapwood and heartwood in both red oak and yellow-poplar. The mineral compositions in sapwood and heartwood are approximately same. Minerals present in biomass ash play a key role in catalyzing pyrolysis reactions (Raveendran et al., 1995; Yang et al., 2006). Raveendran et al. reported that cations, for example potassium and sodium, are responsible for accelerated catalytic decomposition of cellulose and hemicelluloses. Data presented in Table 2.3 show that a considerable amount of sodium and potassium is present in bark, sapwood, and heartwood of both red oak and yellow-poplar. Therefore, there may not be any observable differences in thermal decompositions of samples due to catalysis because all the samples would be catalyzed equally. Ren et al. (2009) observed enhanced conversion 
of nitrogen present in biomass to $\mathrm{NH}_{3}, \mathrm{HCN}, \mathrm{NO}$, and $\mathrm{HCNO}$ at low temperatures when biomass was treated with $\mathrm{KOH}$ and $\mathrm{CaO}$. Therefore, addition of minerals is desirable for fast thermal degradation of biomass but it is not recommended for nitrogen rich biomass to avoid unnecessary nitrogen loss.

Table2.3. Mineral composition in parts per million (ppm) of the physical components (sapwood, heartwood, bark) of red oak and yellow-poplar.

\begin{tabular}{ccccccc}
\hline \multirow{2}{*}{ Sample } & \multicolumn{3}{c}{ Red oak } & \multicolumn{3}{c}{ Yellow-poplar } \\
\cline { 2 - 7 } & Bark & Sapwood & Heartwood & Bark & Sapwood & Heartwood \\
\hline Phosphorus & 408 & 127 & $<60$ & 257 & $<60$ & $<60$ \\
Potassium & 3282 & 1875 & 684 & 1977 & 798 & 826 \\
Calcium & 11670 & 450 & 63 & 8530 & 482 & 1016 \\
Magnesium & 601 & 536 & 241 & 668 & 319 & 429 \\
Manganese & 1690 & 309 & 93 & 1415 & 272 & 364 \\
Iron & 109 & 107 & 54 & 105 & 56 & 51 \\
Aluminum & 78 & 14 & 5 & 248 & 22 & 19 \\
Copper & 2.9 & 2.6 & 1.8 & 5.6 & 1.7 & 1.5 \\
Zinc & 13.3 & 5.2 & 6.3 & 13.0 & 5.4 & 5.1 \\
Sodium & 40 & 18 & 58 & 23 & 34 & 19 \\
\hline
\end{tabular}

In the proximate analysis, the average fixed carbon and volatile matter contents in bark, sapwood and heartwood of yellow-poplar and red oak were around $20 \%$ and $80 \%$, respectively (Table 2.4). This result agrees with previous studies (Adebayo, 2010; Demirbaş, 1997). The ash content in bark (2\% to $3 \%)$ was significant higher than in sapwood and heartwood (around 0.4\%), ( $\mathrm{p}<0.01)$. Also, the ash and fixed carbon contents in lignin polymer were significantly higher than in cellulose and xylan polymers, and the volatile matter in lignin polymer was significantly lower than in the cellulose and xylan polymers $(\mathrm{p}<0.01)$. The fixed carbon content of xylan (around 1.66\%) was significantly lower than in cellulose $(12.56 \%)$ and lignin $(36.71 \%),(\mathrm{p}<0.01)$. The proximate analysis provides vital information about how biomass is expected to behave during pyrolysis. The 
volatile matter content is related to the amount of biomass, excluding water, which can be volatilized by the application of heat. During pyrolysis, these volatiles end-up in either gaseous products or bio-oils. However, proximate analysis provides no information as to where the volatile matter of biomass will end-up, i.e., in the bio-oil or gases. In addition, the fixed carbon represents the ash-free carbon residue left after pyrolysis. In the absence of mass transfer limitations in large batch pyrolysis experiments, quantities of bio-char produced from pyrolysis should be theoretically equal to the sum of fixed carbon content and ash content measured from proximate analysis. However, in practical situations, actual maximum bio-char yield on an-ash free basis were reported to be $57 \%$ (chestnut wood) and $80 \%$ (oak wood) of their respective fixed carbon contents (Antal, 2004).

Table 2.4. Proximate analysis (moisture, ash, volatile and fixed carbon (\% d.b)) of bark, sapwood, and heartwood of red oak and yellow-poplar and wood-polymers (cellulose, xylan and lignin).

\begin{tabular}{llllll}
\hline Property & & Moisture $(\%)$ & Ash $(\%)$ & Volatile $(\%)$ & $\begin{array}{l}\text { Fixed Carbon } \\
(\%)\end{array}$ \\
\hline Red oak & Bark & $6.94 \pm 0.06$ & $3.08 \pm 0.52$ & $77.50 \pm 1.20$ & $19.43 \pm 1.73$ \\
& Sapwood & $0.42 \pm 0.01$ & $0.36 \pm 0.00$ & $81.58 \pm 0.02$ & $18.07 \pm 0.02$ \\
& Heartwood & $6.16 \pm 0.04$ & $0.13 \pm 0.01$ & $81.84 \pm 0.08$ & $18.05 \pm 0.09$ \\
\hline Yellow-poplar & Bark & $7.53 \pm 0.04$ & $2.24 \pm 0.04$ & $77.22 \pm 0.17$ & $20.55 \pm 0.13$ \\
& Sapwood & $6.76 \pm 0.00$ & $0.48 \pm 0.02$ & $83.53 \pm 0.20$ & $16.00 \pm 0.22$ \\
& Heartwood & $6.75 \pm 0.01$ & $0.50 \pm 0.02$ & $83.60 \pm 0.21$ & $15.91 \pm 0.19$ \\
\hline Wood polymers & Cellulose & $5.29 \pm 0.00$ & $0.00 \pm 0.05$ & $87.47 \pm 0.17$ & $12.56 \pm 0.12$ \\
& Xylan & $0.00 \pm 0.01$ & $0.00 \pm 0.00$ & $98.38 \pm 0.12$ & $1.66 \pm 0.13$ \\
& Lignin & $3.03 \pm 0.01$ & $2.19 \pm 0.08$ & $61.10 \pm 0.28$ & $36.71 \pm 0.37$ \\
\hline
\end{tabular}

The contents of cellulose, hemicellulose and lignin in red oak and yellow-poplar are presented in Table 2.5 and Figure 2.2. Lignin content in bark (around 18 to 20\%) was 
relatively higher than in sapwood and heartwood (in the range of $10 \%$ to $15 \%$ ). In contrast, cellulose and hemicellulose contents in red oak bark (around 30\% and 20\%, respectively) were relatively lower than in sapwood and heartwood (around 50\% and 26\%, respectively). Cellulose, hemicellulose and lignin contents in sapwood and heartwood were approximately similar. Similarly, Usia et al. reported that the cellulose contents in sapwood, heartwood and bark of oak were $53.11 \%, 48.61 \%$ and $26.29 \%$, respectively, and the lignin contents in three components were $28.71 \%, 24.14 \%$ and $33.14 \%$, respectively (Usia and Kara, 1997). In Schowalter's report, the concentration of cellulose in oak was $0.52\left(\mathrm{~g} \mathrm{~g}^{-1}\right)$ in sapwood, 0.46 $\left(\mathrm{g} \mathrm{g}^{-1}\right)$ in heartwood, $0.31\left(\mathrm{~g} \mathrm{~g}^{-1}\right)$ in inner bark and $0.18\left(\mathrm{~g} \mathrm{~g}^{-1}\right)$ in outer bark (Schowalter et al., 1998). Percent of biomass reported in 'others' category in Table 2.5 and Figure 2.2 are lumped quantities of fat, protein, extractives, pectin etc, which were not individually measured.

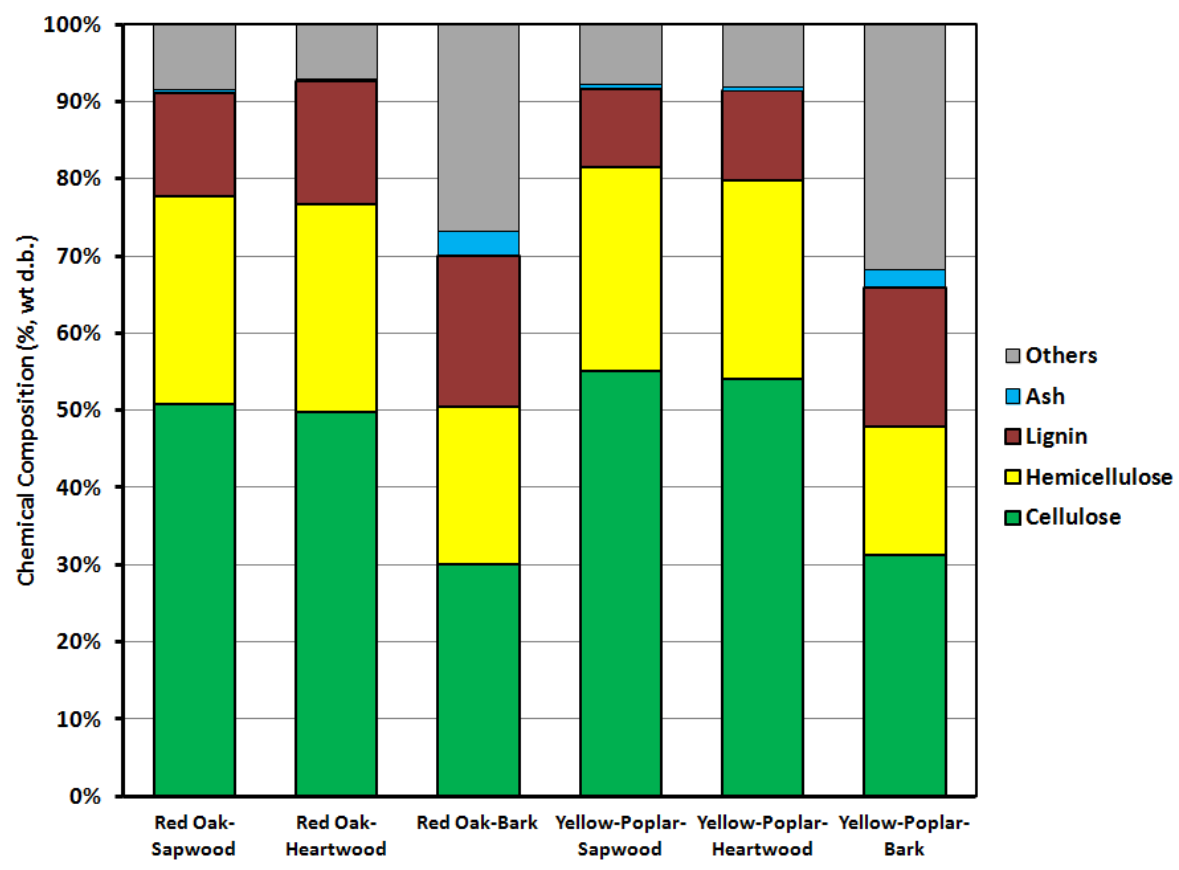

Figure 2.2. Percent cellulose, hemicellulose and lignin contents (d.b.) in bark, sapwood and heartwood of red oak and yellow-poplar samples. 
Table 2.5. Percent cellulose, hemicellulose and lignin contents (d.b.) in bark, sapwood and heartwood of red oak and yellow-poplar samples.

\begin{tabular}{llllll}
\hline Property & & Cellulose (\%) & Hemicellulose (\%) & Lignin (\%) & $\begin{array}{l}\text { Others } \\
(\%)\end{array}$ \\
\hline Red oak & Bark & 30.02 & 20.45 & 19.58 & 26.87 \\
& Sapwood & 50.87 & 26.86 & 13.38 & 8.52 \\
& Heartwood & 49.82 & 26.90 & 15.97 & 7.18 \\
\hline Yellow-poplar & Bark & 31.54 & 16.73 & 17.98 & 31.82 \\
& Sapwood & 55.07 & 26.46 & 10.17 & 7.83 \\
& Heartwood & 54.08 & 25.74 & 11.61 & 8.07 \\
\hline
\end{tabular}

Cellulose, hemicellulose and lignin are the main organic polymers that decompose during pyrolysis (Jeon et al., 2012; Liu et al., 2011; Qu et al., 2011; Raveendran et al., 1996; Yang et al., 2007; Yang et al., 2006). Each polymer behaves distinctly during pyrolysis. Cellulose degrades at $240-350{ }^{\circ} \mathrm{C}$ producing anhydrocellulose and levoglucosan. The latter is produced when a glucosan radical forms, and it does not get a chance to bridge with oxygen present in the cellulose polymer. The in-depth chemistry of this reaction is presented by Mohan et al. (2006). Unlike cellulose, which has only glucose in its chain structure, hemicellulose contains heteropolysaccharide and thermally degrades in the temperature range of 130-194 ${ }^{\circ} \mathrm{C}$ (Mohan et al., 2006). The differences in thermal decomposition chemistry of hemicellulose and cellulose are not well-known. The thermal decomposition of lignin occurs at 280 to $500{ }^{\circ} \mathrm{C}$ yielding phenol via cleavage of ether and carbon-carbon linkages. According to Mohan et al. lignin produces more residual char than cellulose or hemicellulose (Mohan et al., 2006). The liquid component of lignin pyrolysis is composed of menthol, acetic acid, acetone, and water; and the gaseous component is mainly methane, 
ethane, and carbon-monoxide. Qu et al. reported that bio-oil yields were 65\% from cellulose pyrolysis, 53\% from xylan pyrolysis, and 40\% from lignin pyrolysis (Qu et al., 2011). Both Raveendran et al. and $\mathrm{Qu}$ et al. showed that the three biomass polymers decompose independently without interfering with each other (Qu et al., 2011; Raveendran et al., 1996).

\subsubsection{Thermo-Chemical Decomposition Behavior of Cellulose, Xylan, and Lignin}

Figure 2.3 shows the TGA and Differential Thermogravimeric (DTG) graphics of cellulose, xylan and lignin heated from $50{ }^{\circ} \mathrm{C}$ to $700{ }^{\circ} \mathrm{C}$ at the heating rate of $10{ }^{\circ} \mathrm{C} / \mathrm{min}$ under an inert atmosphere. The DTG curves present the rate of fractional conversion and the TGA curves show the percentage weight remaining over the temperature range. As shown in the TGA graphic (Figure 2.3a), cellulose produced $4.45 \%$ char, xylan produced $1.89 \%$ char and lignin produced $41.43 \%$ char when heated to $700{ }^{\circ} \mathrm{C}$. The char yields should match with the sum of fixed carbon and ash content measured from proximate analysis. Similar results of lignin and cellulose char yields were presented earlier (Raveendran et al., 1996; Yang et al., 2005). The reported char yields from cellulose pyrolysis are $2.5 \%$ for Whatman cellulose, $14.0 \%$ for wood cellulose (Raveendran et al., 1996), and 7\% for a fibrous powder form of cellulose (Yang et al., 2006). Similarly, char yield reported for hemicellulose is $20 \%$ for xylan extracted from birchwood (Yang et al., 2006) and 30\% for xylan (Raveendran et al., 1996).The reported char yield for lignin is $40.6 \%$ for alkali lignin, $47.1 \%$ for acid lignin (Raveendran et al., 1996) and 40\% for alkali lignin in brown powder form (Yang et al., 2006). Raveendran et al. reported that cellulose present in different biomass differs due to its varying crystallinity (Raveendran et al., 1996), which not only affects the char yield but also the thermal degradation behavior. Char produced from xylan was lower than that reported in 
the literature. This difference is attributed to the dissimilar variety of xylan resulting in different structural and chemical properties.

When looking at the DTG graphics, cellulose decomposed dramatically in the temperature range of $300{ }^{\circ} \mathrm{C}$ to $400{ }^{\circ} \mathrm{C}$ with a large decomposition peak at $340{ }^{\circ} \mathrm{C}$. Xylan decomposed in the temperature range of $150{ }^{\circ} \mathrm{C}$ to $400{ }^{\circ} \mathrm{C}$ with a large decomposition peak at $200{ }^{\circ} \mathrm{C}$. Degradation of lignin occurred in the temperature range of $100{ }^{\circ} \mathrm{C}$ to $700{ }^{\circ} \mathrm{C}$ with a tiny degradation peak at $340{ }^{\circ} \mathrm{C}$ (Figure 2.3b). Similar results for lignin and cellulose degradation temperature range and peak location were presented in the literature (Raveendran et al., 1996; Yang et al., 2005). However, the large peak for xylan degradation was reported at $260{ }^{\circ} \mathrm{C}$ (Yang et al., 2005) and $300{ }^{\circ} \mathrm{C}$ (Raveendran et al., 1996). Furthermore, the reported decomposition temperature range for xylan was between $200{ }^{\circ} \mathrm{C}$ to $350{ }^{\circ} \mathrm{C}$ (Raveendran et al., 1996; Yang et al., 2005). Different results may be caused by a dissimilar variety of xylan and TGA test conditions. Yang et al. used xylan from birchwood (Sigma-Aldrich Ghemie GMbH). Raveendran et al. heated xylan from room temperature to $1000{ }^{\circ} \mathrm{C}$ at the heating rate of $50{ }^{\circ} \mathrm{C} / \mathrm{min}$ under an inert atmosphere.

Different thermal degradation behavior of cellulose, hemi-cellulose, and lignin is attributed to their individual chemical natures (Yang et al., 2006). Among the three polymers, hemicellulose (xylan) has random amorphous structures with reactive acetyl groups that are easily broken down during acid hydrolysis. An average polymer of hemicellulose contains only 150 monomers of repeating saccharides. Unlike cellulose, which has only glucose in its chain structure, hemicellulose contains heteropolysaccharide and thermally degrades in the temperature range of $130-194^{\circ} \mathrm{C}$ (Mohan et al., 2006). In contrast, cellulose is a linear polymer of glucose (5000-10000 glucose units). The cellulose 
degrades at $240-350^{\circ} \mathrm{C}$ producing anhydrocellulose and levoglucosan (Mohan et al., 2006). Celluloice polymer contains some crystalline and some amorphous regions. The crystalline regions are resistant to acid hydrolysis or solvent penetration. Ligninic polymers are highly branched, substituted, mononuclear aromatic polymers forming a lignocellulosic complex in the biomass, and this amorphous structure of lignin accounts for 16 to $33 \%$ of the mass of woody biomass (Mohan et al., 2006). The thermal decomposition of lignin occurs at 280 to $500^{\circ} \mathrm{C}$ yielding phenol via cleavage of ether and carbon-carbon linkages.
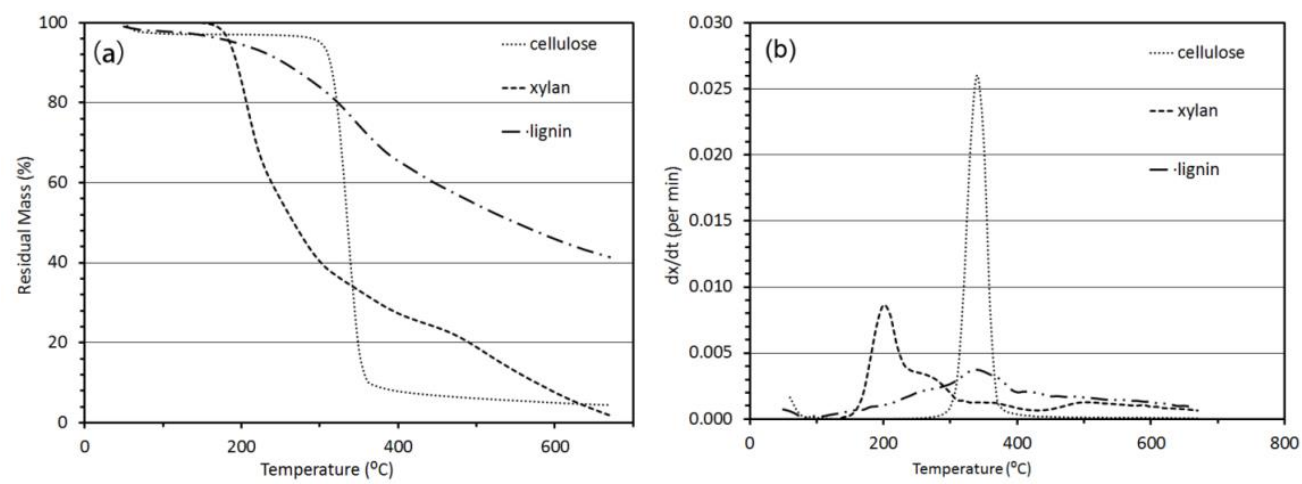

Figure 2.3. Thermo-gravimetric analysis results showing (a) TGA-percentage weight remaining, and (b) DTG-rate of fractional changes when samples of cellulose, xylan and lignin are heated from $50^{\circ} \mathrm{C}$ to $700^{\circ} \mathrm{C}$ at the heating rate of $10^{\circ} \mathrm{C} / \mathrm{min}$ under an inert atmosphere.

\section{Activation Energy Analysis}

Figure 2.4 shows the activation energy and $\mathrm{dX} / \mathrm{dt}$ curves of cellulose, xylan and lignin as a function of fractional conversion from 0.01 to 0.9 . Valid activation energy values of cellulose, xylan and lignin were calculated in the fractional conversion range of 0.01 to $0.9,0.01$ to 0.4 and 0.01 to 0.5 , respectively (Figure 2.4 ). The activation energy values in the fractional conversion range of 0.5 to 0.9 and 0.6 to 0.9 for xylan and lignin are not reported here due to their negative numerical values. The negative values could be the result of following three reasons: (1) the isoconversion model is not valid for certain fractional 
conversion values, (2) the Arrhenius law is may not be applied to certain fractional conversion values, (3) overlapping multiple reactions are taking place. Therefore, the authors state that the isoconversion model does not appear to be appropriate for every value of fractional conversion.

As shown in Figure 2.4a, the activation energy of cellulose ranged from 208 $\mathrm{kJ} / \mathrm{mol}$ to $381 \mathrm{~kJ} / \mathrm{mol}$ for the fractional conversions range of 0.2 to 0.9 , which corresponds to the temperature range of $320{ }^{\circ} \mathrm{C}$ to $360{ }^{\circ} \mathrm{C}$. A similar result for the cellulose activation energy (242 kJ/mol) was presented by Bradbury et al. (1979) using an isothermal method. (Chen and Kuo, 2011) reported activation energy values of $124 \mathrm{~kJ} / \mathrm{mol}$ for cellulose but in the temperature range of $200^{\circ} \mathrm{C}$ to $300^{\circ} \mathrm{C}$ under isothermal heating condition. Also, cellulose activation energies of $194 \mathrm{~kJ} / \mathrm{mol}$ and $195 \mathrm{~kJ} / \mathrm{mol}$ in the temperature range of $300^{\circ} \mathrm{C}$ to $400^{\circ} \mathrm{C}$ were reported by Kissinger and Kamal's method (Alvarez and Vázquez, 2004). These different values of activation energies are the result of not only different calculation methods as documented by Gaur and Reed (1998) and Chen and Kuo (2011) but also the different crystallinity of the cellulose being used in these studies.

As shown in Figure 2.4b, the activation energy of xylan was in the range of 88 $\mathrm{kJ} / \mathrm{mol}$ to $348 \mathrm{~kJ} / \mathrm{mol}$ in the fractional conversion range of 0.1 to 0.4 with an additional high activation energy $745 \mathrm{~kJ} / \mathrm{mol}$ shown at the fractional conversion 0.37 corresponding to temperature $225^{\circ} \mathrm{C}$. Otherwise for temperatures from 185 to $215^{\circ} \mathrm{C}$, the activation energy values fall between 150 and $250 \mathrm{~kJ} / \mathrm{mol}$. Similar, activation energy values have been reported in the literature, for example, $252 \mathrm{~kJ} / \mathrm{mol}$ in the temperature range of $200^{\circ} \mathrm{C}$ to $300^{\circ} \mathrm{C}$ using isothermal heating (Chen and Kuo, 2011), Some other studies reported activation energy values are $109 \mathrm{~kJ} / \mathrm{mol}$ in the temperature range of $225-265{ }^{\circ} \mathrm{C}$ and 105 
$\mathrm{kJ} / \mathrm{mol}$ in the temperature range of $270-320{ }^{\circ} \mathrm{C}$ (Ramiah, 1970). Again, varying values of activation energy for xylan are directly related to the source of xylan and the method used in calculating the activation energy.

As shown in Figure 2.4c, the activation energy of lignin constantly increased as a response to rising temperature from 50 to $370^{\circ} \mathrm{C}$ in the fractional conversion range of 0.01 to 0.5 . A major increase in activation energy was calculated in the fractional conversion 0.4 to 0.5 corresponding to the temperature range of 340 to $370^{\circ} \mathrm{C}$. The maximum activation energy of lignin was $801 \mathrm{~kJ} / \mathrm{mol}$ at a fractional conversion of 0.5 . Lignin activation energy was reported to be $38 \mathrm{~kJ} / \mathrm{mol}$ (Chen and Kuo, 2011) under isothermal heating condition, and $284 \mathrm{~kJ} / \mathrm{mol}$ (Murugan et al., 2008) in the temperature range of $200^{\circ} \mathrm{C}$ to $300^{\circ} \mathrm{C}$. Different activation energy values of lignin may be attributed to the calculation methods, source of lignin, and the method used in the extraction of lignin. For example, Ramiah (Ramiah, 1970) reported that lignin extracted from spruce wood sawdust by periodate oxidation and hydrolysis had an activation energy value of $54.39 \mathrm{~kJ} / \mathrm{mol}$ whereas lignin extracted from douglas fir by digesting in sulfuric acid and hydrolysis had an activation energy value of $79.50 \mathrm{~kJ} / \mathrm{mol}$. Also, lignin type changes with wood species. Softwood and hardwood have varying proportions of three monomers (p-coumaryl alcohol; coniferyl alcohol; and sinapyl alcohol), which are precursors to lignin polymers. Hardwood lignin contains mainly coniferyl and sinapyl-based alcohols whereas softwood lignin contains mainly coniferyl alcohol with little p-coumaryl alcohol. 

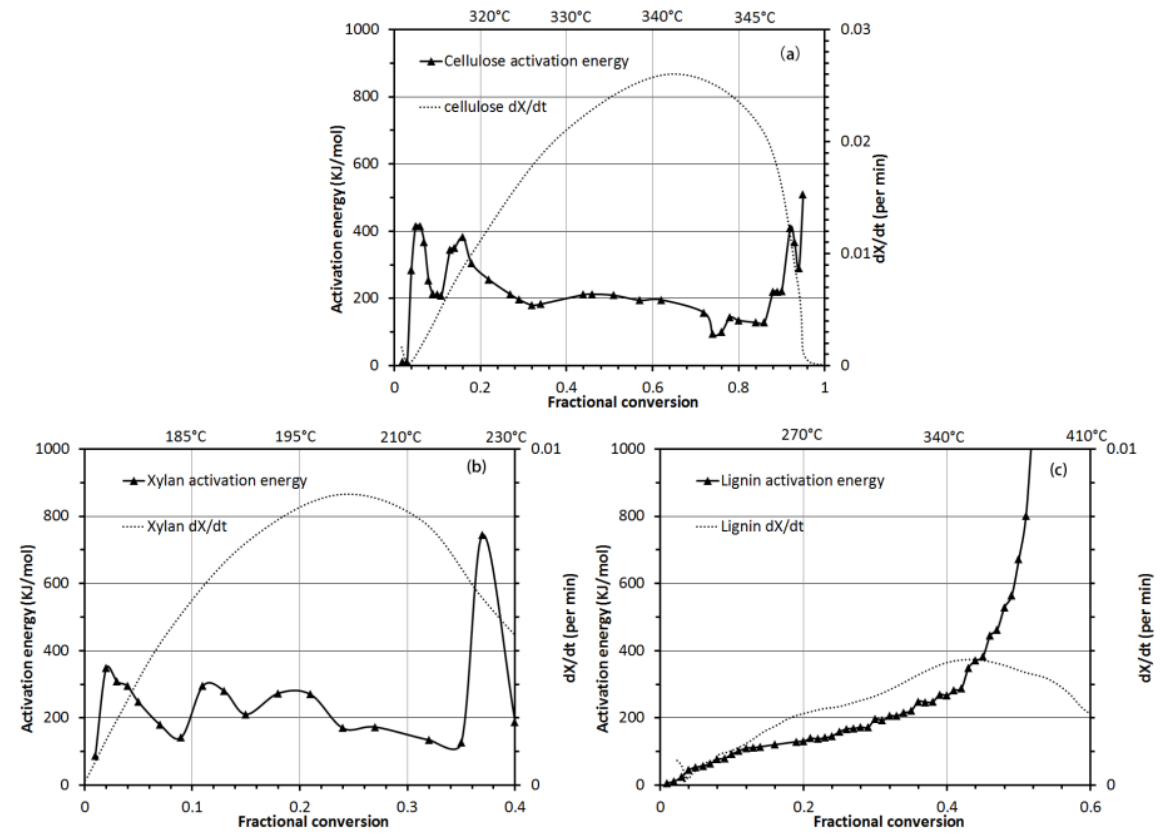

Figure 2.4. Activation energy and dX/dt curves of (a) cellulose, (b) xylan and (c) kraft lignin as a function of fractional conversion from 0.01 to 0.9 .

\subsubsection{Thermo-Chemical Decomposition Behavior of Wood Components}

\section{Thermogravimetric Analysis}

Experimental char yields were $14.74 \%$ for sapwood, $14.26 \%$ for heartwood, and 22.69 for bark samples of yellow-poplar. An attempt was made to calculate the char yields for sapwood, heartwood, and bark using their chemical composition data presented in Table 2.5. TGA char-yield data for individual model wood polymers (cellulose, xylan, and lignin) are presented in section 3.2, and assumed 26.9\% char yield from extractives (Raveendran et al., 1996). The calculated and measured char yields (calculated, measured) were (10.55\%, $15.61 \%)$ for sapwood, $(11.22 \%, 15.60 \%)$ for heartwood, and $(17.02 \%, 23.45 \%)$ for red oak samples. As can be seen, the char yields calculated from models of wood polymers and the chemical composition of wood are different from the experimentally measured char yields. These differences are directly related to the differences in the chemical nature of cellulose, 
xylan, and lignin used as model wood polymers and those actually present in the sapwood, heartwood, and bark samples.
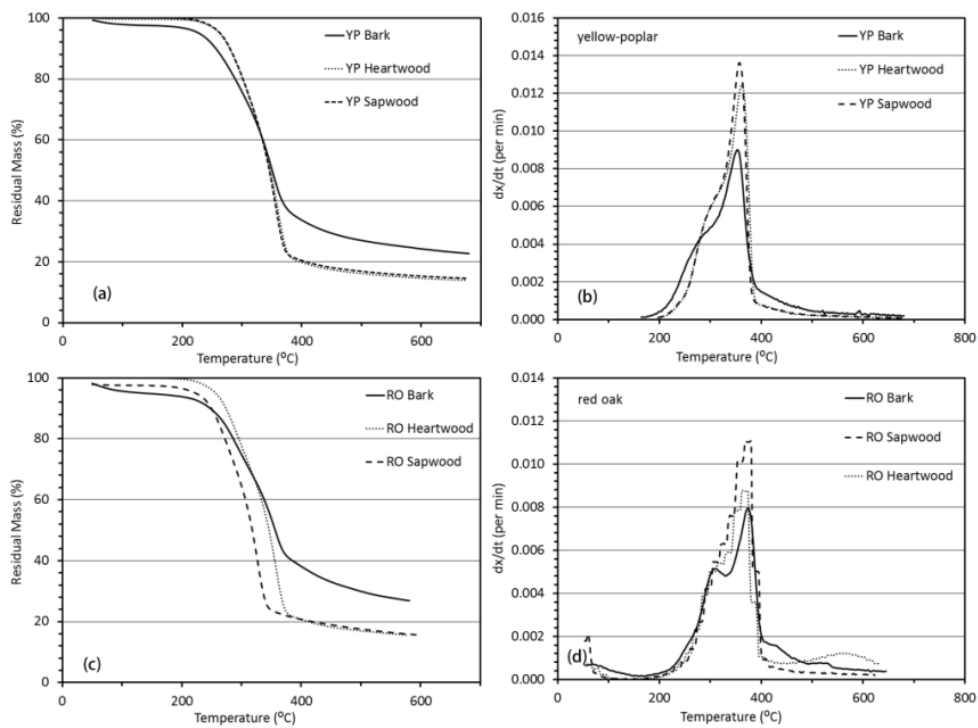

Figure 2.5. Thermo-gravimetric analysis results showing rate of percentage weight remaining when samples of (a) yellow-poplar and (c) red oak's components (bark, sapwood and heartwood), and rate of fractional changes when samples (b) yellow-poplar and (d) red oak's components (bark, sapwood and heartwood) heated from $50^{\circ} \mathrm{C}$ to $700^{\circ} \mathrm{C}$ at the heating rate of $10^{\circ} \mathrm{C} / \mathrm{min}$ under an inert atmosphere.

Raveendran et al., (1996) reported that crystallinity of cellulose varies from 34.4 for Whatman cellulose to 91.5 for highly crystalline cellulose used in chromatography instrument columns and it directly affects thermal decomposition of wood. Wood cellulose crystallinity is somewhere around 68.9. Due to the difference in crystallinity, wood cellulose produced $14 \%$ char whereas Whatman cellulose produced $2.5 \%$ char. Therefore, low crystallinity cellulose produces low quantities of char because it has more amorphous regions to react during pyrolysis than highly crystalline cellulose. Raveendran et al. did not find such large differences between xylan and wood extracted hemicellulose char yields. Char yields for lignin polymers may vary from 47.1 for acid-extracted lignin to 40.6 alkali- 
extracted lignin (Raveendran et al., 1996).There are other methods for lignin extraction as discussed in Fengel and Wegeber (Dietrich Fengel, 2003) and each extraction method significantly alters the amorphous chemical structure of lignin, which might explain different char yields from different lignins obtained from TGA graphics.

The TGA graphics were used to calculate DTG graphics to plot rate of fractional conversion as the function of temperature. The DTG graphics provide visual information as to when pyrolysis reactions are taking place and the rates of fractional conversion. Within the DTG graphics, there are three things to watch for, first, location of peaks, second, relative height of peaks, and third, broadness of DTG graphic on the temperature scale. In the DTG graphic (Figure 2.5), two obvious peaks were observed for bark, sapwood and heartwood in the temperature ranges of $250^{\circ} \mathrm{C}$ to $350^{\circ} \mathrm{C}$ and $350^{\circ} \mathrm{C}$ to $400^{\circ} \mathrm{C}$, respectively (Figure $2.5 \mathrm{~b}$, Figure $2.5 \mathrm{~d}$ ). The first peak at $280^{\circ} \mathrm{C}$ accounted for the degradation of hemicellulose and the later peak at $360^{\circ} \mathrm{C}$ was mainly due to cellulose decomposition. Raveendran et al. reported the following prominent events that can be observed in DTG: mainly moisture evolution below $100^{\circ} \mathrm{C}$; start of extractive decomposition between 100 and $250^{\circ} \mathrm{C}$, mainly hemicelluloses decomposition between 250 and $350{ }^{\circ} \mathrm{C}$, cellulose decomposition between 350 and $500^{\circ} \mathrm{C}$ and lignin decomposition beyond $500^{\circ} \mathrm{C}$. Interestingly, cellulose and hemicelluloses peaks are more separated for bark samples, whereas, the hemicelluloses peak is visible only as a shoulder for the sapwood and heartwood samples. These separations may very well be explained by noting the celluloseto-hemicellulose ratios calculated from chemical composition data presented in Table 2.5. The calculated cellulose-to-hemicellulose ratios were 1.9 for sapwood and heartwood and 1.5 for bark of the red oak samples. Similarly, the ratios were 2.1 for sapwood and 
heartwood and 1.9 for bark samples of the yellow-poplar. It is evident that a low celluloseto-hemicellulose ratio produces a clear separation of the hemicellulose peak which is why the red oak bark showed more visible separation of the hemicellulose peak than yellowpoplar bark.

Another visible difference was the height of peaks which correspond to the rate of decomposition. At both peaks, sapwood and heartwood showed higher decomposition rates than bark for both yellow-poplar and red oak. This behavior is caused by the amount of cellulose or hemicellulose present in biomass. For example, sapwood had the highest cellulose content; therefore, it showed the largest peak height at $360^{\circ} \mathrm{C}$. In contrast, bark had the lowest cellulose content; therefore, it showed the lowest peak height at the same temperature. Finally, broadness of the DTG curve is associated with lignin and extractive decomposition because both lignin and extractives decompose in a very broad temperature range. The only difference between the two is that extractives decompose at higher rates than lignin but at lower temperatures (Raveendran et al., 1996). Raveendran et al. reported that the extractives derived from wood decomposed between 150 to $400^{\circ} \mathrm{C}$, whereas lignin decomposed between 250 and $450{ }^{\circ} \mathrm{C}$. Therefore, a high lignin-to-extractive ratio should provide insight into the broadness of DTG curve. If the DTG curve is broadened towards the right side of the cellulose peak, the lignin-to-extractive ratio is low and vice versa. From the chemical composition data in the Table 2.5 , this ratio was 0.6 for yellow-poplar bark and 0.7 for red oak bark. Therefore, extra broadness is visible on the right side of the cellulose peak for red oak bark in the DTG graphics. 


\section{Activation Energy Analysis}

Figure 2.6 shows the activation energy and dX/dt curves of (a) bark, (b) heartwood and (c) sapwood for yellow-poplar as a function of fractional conversion from 0.01 to 0.9 . These activation energy values should be the result of the combined effects of the individual wood polymers. The key observations about the activation energy pattern for bark, heartwood and sapwood in Figure 2.6 are following: 1. A "three-zone" degradation occurred for sapwood and heartwood ( $<0.2$ fractional conversion; 0.2-0.9 fractional conversion; and $>0.9$ fractional conversion), 2. A "three-zone" degradation occurred for bark ( $<0.4$ fractional conversion, 0.4 to 0.8 fractional conversion, and $>0.8$ fractional conversion), and 3 . Activation energy values for bark remained higher than the other two wood components for all conversions.

The three-zone degradation for sapwood and heartwood $(<0.2$ fractional conversion; 0.2-0.9 fractional conversion; and >0.9 fractional conversion) may be explained by their respective zone-temperatures and the chemical compositions of sapwood and heartwood (moisture, extractive, cellulose, hemicellulose, and lignin contents). The activation energy below 0.2 fractional conversions ranged from 265 to $296 \mathrm{~kJ} / \mathrm{mol}$, which may very well be related to moisture evolution and extractive decompositions. Both sapwood and heartwood had a total of $14.3 \%$ of moisture and extractive content. Also, up to 0.2 fractional conversion, degradation took place below $295^{\circ} \mathrm{C}$, which is the temperature range for moisture evolution and extractive decomposition (Raveendran et al., 1996). The activation energy for moisture evolution below $100{ }^{\circ} \mathrm{C}$ is reported to be in the range of 29.35 to $33.78 \mathrm{~kJ} / \mathrm{mol}$, which is basically related to the evaporation of the free and some bound water (Mirzaee et al., 2009). Above $100{ }^{\circ} \mathrm{C}$ but below $295{ }^{\circ} \mathrm{C}$, all bound water 
including water of constitution (water molecules connected to cellulose polymers by highenergy hydrogen bonds) is driven off. In the same temperature range, extractives decompose. In the second zone, mainly cellulose and hemicelluloses decompose between 0.2 and 0.9 fractional conversion temperatures between $295^{\circ} \mathrm{C}$ to $365^{\circ} \mathrm{C}$. Both sapwood and heartwood had approximately a total of $76 \%$ cellulose and hemicellulose and cumulatively 90\% of sapwood and heartwood was made-up of moisture, extractives, cellulose, and hemicellulose. The activation energy between 0.2 and 0.9 fractional conversions stayed around 240 to $260 \mathrm{~kJ} / \mathrm{mol}$. The reported activation energy values for 0.70 conversion are $209 \mathrm{~kJ} / \mathrm{mol}$ (Slopiecka et al., 2012) and $265 \mathrm{~kJ} / \mathrm{mol}$ (Singh et al., 2012). Finally, activation energy above fractional conversion of 0.9 fluctuated between 286 to $449 \mathrm{~kJ} / \mathrm{mol}$, mainly for the decomposition of the remaining $10 \%$ lignin. Beall reported activation energy of wood lignin decomposition to be $135.98 \mathrm{~kJ} / \mathrm{mol}$ in the temperature range of $398{ }^{\circ} \mathrm{C}$ to $439^{\circ} \mathrm{C}$, which was calculated by a differential-difference method (Beall, 1969).

As mentioned before, decomposition of bark also took place in three fractional conversion zones $(<0.4$ fractional conversion, 0.4 to 0.8 fractional conversion, and $>0.8$ fractional conversion) but activation energy values for bark remained higher than the other two wood components for all conversions. The first decomposition zone for bark lasted until 0.4 fractional conversion below $315^{\circ} \mathrm{C}$, which reflected decomposition of its combined $37 \%$ moisture and extractives. The activation energy in this decomposition zone was between 260 and $296 \mathrm{~kJ} / \mathrm{mol}$. In the second fractional conversion zone (0.4 to 0.8 ), the combined 44\% hemicellulose and cellulose degraded with activation energy in the range of 256 to 309 $\mathrm{kJ} / \mathrm{mol}$ until the temperature reached $375^{\circ} \mathrm{C}$. After the fractional conversion of 0.8 for bark, the activation energy reached as high as $943 \mathrm{~kJ} / \mathrm{mol}$ due to lignin decomposition as 
temperatures soared above $600{ }^{\circ} \mathrm{C}$. Additionally, overall activation energy values for bark decomposition were attributed to the high extractive and lignin content of the bark compared to the sapwood and heartwood.
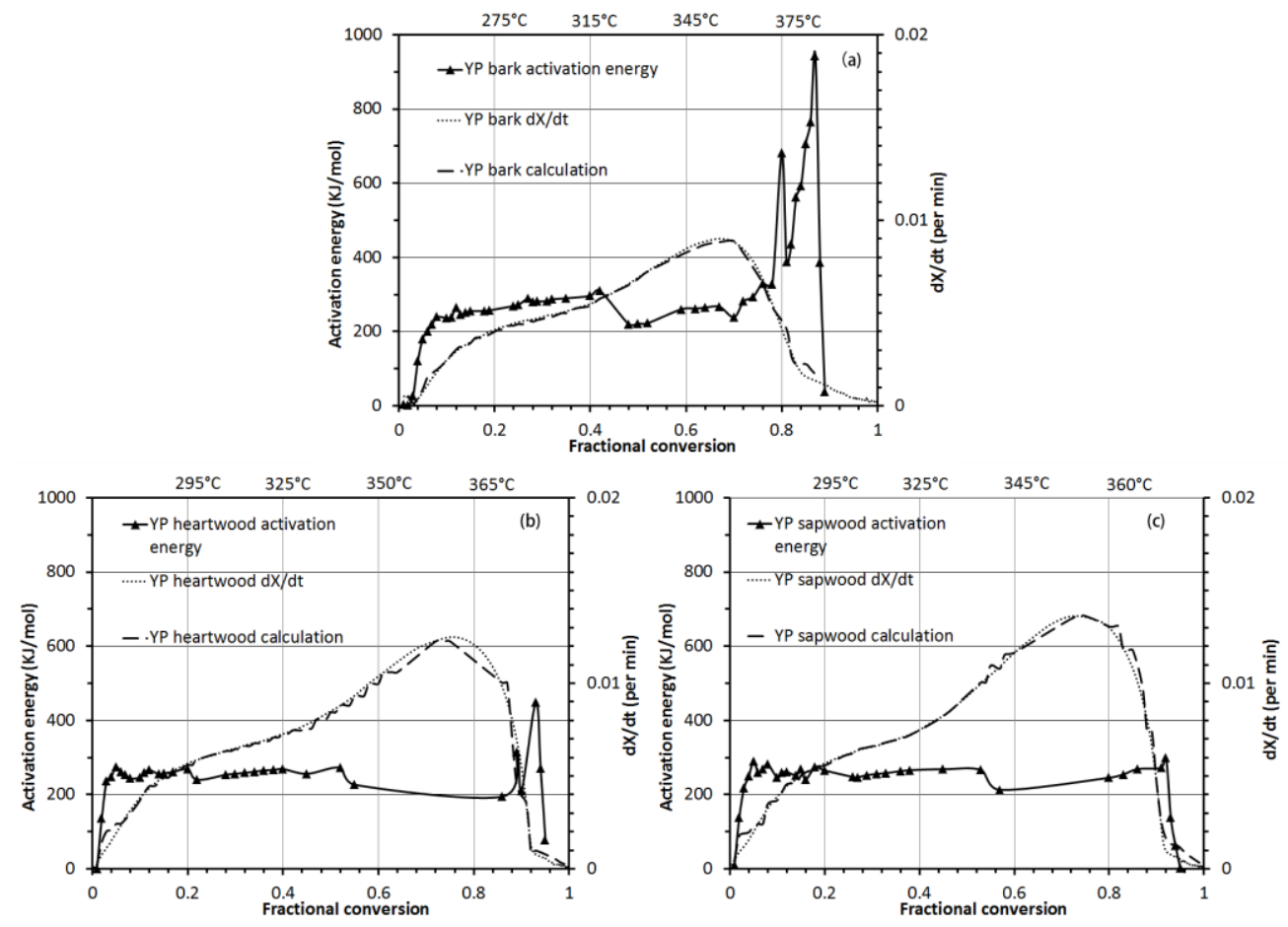

Figure 2.6. Activation energy and $\mathrm{dX} / \mathrm{dt}$ (experimental and calculated) curve of (a) bark, (b) heartwood and (c) sapwood of yellow-poplar as a function of fractional conversion from 0.01 to 1.0.

Figure 2.6 also shows plots for $\mathrm{dX} / \mathrm{dt}$ calculated using activation energy values, pre-exponential factor values, and an assumed order of reaction equal to 1 . The calculated $\mathrm{dX} / \mathrm{dt}$ curve closely followed the experimental $\mathrm{dX} / \mathrm{dt}$ curve, which suggested that the isoconversion method applied in this paper for the determination of the kinetics is valid for wood pyrolysis 


\subsection{Conclusions}

Biomass components (bark, sapwood and heartwood) of red oak and yellowpoplar and wood polymers (cellulose, xylan and lignin) were evaluated for calorific value, cell wall specific gravity, proximate analysis, mineral analysis and ultimate analysis. There is no significant difference for the results of the cell wall specific gravity, calorific value and ultimate analysis among bark, sapwood and heartwood for red oak and yellow-poplar. In addition, the thermo-chemical decomposition behavior of the individual wood polymers (cellulose, xylan and lignin) and red oak and yellow-poplar components (bark, sapwood and heartwood) was also examined. Cellulose showed activation energy values in the range of 208 to $381 \mathrm{~kJ} / \mathrm{mol}$ during decomposition whereas xylan and lignin had maximum activation energy values of $348 \mathrm{~kJ} / \mathrm{mol}$ and $801 \mathrm{~kJ} / \mathrm{mol}$ at fractional conversions of 0.4 and 0.5 , respectively. The activation energy requirement for wood components remained within the range of $233 \mathrm{~kJ} / \mathrm{mol}$ to $388 \mathrm{~kJ} / \mathrm{mol}$ until $365^{\circ} \mathrm{C}$ and then peaked to roughly $943 \mathrm{~kJ} / \mathrm{mol}, 449$ $\mathrm{kJ} / \mathrm{mol}$ and $298 \mathrm{~kJ} / \mathrm{mol}$ for bark, heartwood and sapwood at $375^{\circ} \mathrm{C}$ where major energy input for lignin decomposition is needed. Also, it was observed that the isoconversion methods may not work for all the fractional conversion values for individual wood polymers but the method worked well for the wood components.

\subsection{Acknowledgments}

This research was funded by the United States Department of Agriculture's McStennis Grant. 


\section{References}

Adebayo, A., J. Wang, B. Dawson-Andoh, J. McNeel, and J. Armstrong. 2009. Assessment of Appalachian hardwood residue properties and potentials for bioenergy utilization. Wood and Fiber Science 41(1):74-83.

Adebayo, A. B. 2010. Pretreatments and energy potentials of appalachian hardwood residues for biofuel production. Dissertation. West Virginia University.

Alvarez, V. A., and A. Vázquez. 2004. Thermal degradation of cellulose derivatives/starch blends and sisal fibre biocomposites. Polymer Degradation and Stability 84(1):13-21.

Antal, M. J. a. G., M. 2004. The art, science, and technology of charcoal production. Fuel and Energy Abstracts 45(1):9.

ASAE Standards S269.4. 1998. Cubes, pellets, and crumbles-definitions and methods for determining density, durability, and moisture content; ASAE: St. Joseph, MI, USA.

ASTM Committee on Standards. 1998. Standard test method for gross calorific value of coal and coke; Standard No. ASTM D5865-98a; The American Society for Tesing and Materials: West Conshohocken, PA, USA.

ASTM Committee on Standards. 2011. Standard test method for ash in the analysis sample of coal and coke from coal; Standard No. ASTM D3174-12; The American Society for Tesing and Materials: West Conshohocken, PA, USA.

Balat, M. 2006. Biomass energy and biochemical conversion processing for fuels and chemicals. Energy Sources, Part A: Recovery, Utilization, and Environmental Effects 28(6):517-525.

Balat, M., M. Balat, E. Kirtay, and H. Balat. 2009. Main routes for the thermo-conversion of biomass into fuels and chemicals. Part 1: Pyrolysis systems. Energy Conversion and Management 50(12):3147-3157.

Beall, F. 1969. Thermogravimetric analysis of wood lignin and hemicelluloses. Wood and Fiber Science 1(3):215-226.

Beall, F. C., and H. W. Eickner. 1970. Thermal degradation of wood components: A review of the literature; U.S. Forest Products Laboratory: Madison, WI, USA.

Biagini, E., F. Barontini, and L. Tognotti. 2006. Devolatilization of biomass fuels and biomass components studied by TG/FTIR technique. Industrial \& Engineering Chemistry Research 45(13):4486-4493. 
Bradbury, A. G. W., Y. Sakai, and F. Shafizadeh. 1979. A kinetic model for pyrolysis of cellulose. Journal of Applied Polymer Science 23(11):3271-3280.

Chen, W.-H., and P.-C. Kuo. 2011. Isothermal torrefaction kinetics of hemicellulose, cellulose, lignin and xylan using thermogravimetric analysis. Energy 36(11):6451-6460.

Corder, S.E. 1976. Properties and uses of bark as an energy source. In Proceedings of the XVI IUFRO World Congress, Oslo, Norway.

Demirbas, A. 2005. Potential applications of renewable energy sources, biomass combustion problems in boiler power systems and combustion related environmental issues. Progress in Energy and Combustion Science 31(2):171-192.

Demirbaş, A. 1997. Calculation of higher heating values of biomass fuels. Fuel 76(5):431434.

Demirbaş, A. 2001. Biomass resource facilities and biomass conversion processing for fuels and chemicals. Energy Conversion and Management 42(11):1357-1378.

Fengel, D. and G. Wegener. 1984. Wood chemistry, ultrastructure, reactions. In Walter de Gruyter, Berlin,Germany.

Gaur, S. a. T. B. R. 1998. Thermal data for natural and synthetic fuels. Marcel Decker, Inc., New York, NY.

Herrera, A., S. Soria, and C. de Araya. 1986. A kinetic study on the thermal decomposition of six hardwood species. European Journal of Wood and Wood Products 44(9):357-360.

Jeon, M.-J., J.-K. Jeon, D. J. Suh, S. H. Park, Y. J. Sa, S. H. Joo, and Y.-K. Park. 2012. Catalytic pyrolysis of biomass components over mesoporous catalysts using Py-GC/MS. Catalysis Today in progress.

Singh, K., J. Zondlo, J. Wang, L. Sivanandan and J.S. Brar. 2012. Influence of environmental decomposition of logging residues on fuel properties. Biological Engineering Transactions 5(4):163-176.

Kim, S.-S., and F. A. Agblevor. 2007. Pyrolysis characteristics and kinetics of chicken litter. Waste Management 27(1):135-140.

Kim, S.-S., J.-K. Jeon, Y.-K. Park, and S. Kim. 2005. Thermal pyrolysis of fresh and waste fishing nets. Waste Management 25(8):811-817.

Kim, S.-S., and S. Kim. 2004. Pyrolysis characteristics of polystyrene and polypropylene in a stirred batch reactor. Chemical Engineering Journal 98(1-2):53-60. 
Lifecycle Greenhouse Gas Emissions Due to Increased Biofuel Production; ICF International: Fairfax, VA, USA, 2009. Web 9 January 2013.

Liu, Q., Z. Zhong, S. Wang, and Z. Luo. 2011. Interactions of biomass components during pyrolysis: A TG-FTIR study. Journal of Analytical and Applied Pyrolysis 90(2):213-218.

McKendry, P. 2002. Energy production from biomass (part 2): conversion technologies. Bioresource technology 83(1):47-54.

Miller, R.S.; Bellan, J. 1996. Analysis of reaction products and convertion time in the pyrolysis of cellulose and wood particles. Combust. Sci. Technol 119: 331-373.

Mirzaee, E., S. Rafiee, A. Keyhani, and Z. Emam-Djomeh. 2009. Determining of moisture diffusivity and activation energy in drying of apricots. Research in Agricultural Engineering 55(3):114-120.

Mohan, D., C. U. Pittman, and P. H. Steele. 2006. Pyrolysis of wood/biomass for bio-oil: A critical review. Energy \& Fuels 20(3):848-889.

Murugan, P., N. Mahinpey, K. E. Johnson, and M. Wilson. 2008. Kinetics of the pyrolysis of lignin using thermogravimetric and differential scanning calorimetry methods. Energy \& Fuels 22(4):2720-2724.

Nitschke, C. R., and J. L. Innes. 2008. Integrating climate change into forest management in South-Central British Columbia: An assessment of landscape vulnerability and development of a climate-smart framework. Forest Ecology and Management 256(3):313-327.

Panwar, N. L., R. Kothari, and V. V. Tyagi. 2012. Thermo chemical conversion of biomass - Eco friendly energy routes. Renewable and Sustainable Energy Reviews 16(4):1801-1816.

Qu, T., W. Guo, L. Shen, J. Xiao, and K. Zhao. 2011. Experimental study of biomass pyrolysis based on three major components: hemicellulose, cellulose, and lignin. Industrial \& Engineering Chemistry Research 50(18):10424-10433.

Ramiah, M. V. 1970. Thermogravimetric and differential thermal analysis of cellulose, hemicellulose, and lignin. Journal of Applied Polymer Science 14(5):1323-1337.

Raveendran, K., A. Ganesh, and K. C. Khilar. 1995. Influence of mineral matter on biomass pyrolysis characteristics. Fuel 74(12):1812-1822.

Raveendran, K., A. Ganesh, and K. C. Khilar. 1996. Pyrolysis characteristics of biomass and biomass components. Fuel 75(8):987-998. 
Ren, Q., C. Zhao, X. Wu, C. Liang, X. Chen, J. Shen, G. Tang, and Z. Wang. 2009. Effect of mineral matter on the formation of NOX precursors during biomass pyrolysis. Journal of Analytical and Applied Pyrolysis 85(1-2):447-453.

Schowalter, T. D., Y. L. Zhang, and T. E. Sabin. 1998. Decomposition and nutrient dynamics of oak wuercus spp. logs after five years of decomposition. Ecography 21(1):3-10.

Sharma, N., and R. Rowe. 1992. Managing the world's forests. Finance \& Development 29(2):31-31.

Slopiecka, K., P. Bartocci, and F. Fantozzi. 2012. Thermogravimetric analysis and kinetic study of poplar wood pyrolysis. Applied Energy 97(0):491-497.

Stokes, R. D. P. B. J. 2011. U.S. billion-ton update: biomass supply for a bioenergy and bioproducts industry. U.S. Department of Energy ORNL/TM-2011/224. Oak Ridge.

U.S. Energy Information Administration. Annual Energy Outlook 2012, Web. 21 June 2013.

Usia, M., and S. Kara. 1997. The chemical composition of wood and bark of Cedrus libani A. Rich. European Journal of Wood and Wood Products 55(2):268-268.

Vincent, J. F. 1999. From cellulose to cell. Journal of Experimental Biology 202(23):32633268.

Wright, M. M., D. E. Daugaard, J. A. Satrio, and R. C. Brown. 2010. Techno-economic analysis of biomass fast pyrolysis to transportation fuels. Fuel 89, Supplement 1(0):S2-S10.

Xu, C., and N. Lad. 2007. Production of heavy oils with high caloric values by direct liquefaction of woody biomass in sub/near-critical water. Energy \& Fuels 22(1):635-642.

Yaman, S. 2004. Pyrolysis of biomass to produce fuels and chemical feedstocks. Energy Conversion and Management 45(5):651-671.

Yang, H., R. Yan, H. Chen, D. H. Lee, and C. Zheng. 2007. Characteristics of hemicellulose, cellulose and lignin pyrolysis. Fuel 86(12-13):1781-1788.

Yang, H., R. Yan, H. Chen, C. Zheng, D. H. Lee, and D. T. Liang. 2005. In-depth investigation of biomass pyrolysis based on three major components: hemicellulose, cellulose and lignin. Energy \& Fuels 20(1):388-393.

Yang, H., R. Yan, H. Chen, C. Zheng, D. H. Lee, and D. T. Liang. 2006. Influence of mineral matter on pyrolysis of palm oil wastes. Combustion and Flame 146(4):605-611. 
CHAPTER 3: CATALYTIC UPGRA DING OF PYROLYSIS VAPOR S USING B I O-CHAR S A S C A T A L Y S T

\subsection{Introduction}

Renewable energy has received renewed attention in recent years in light of the increasing fossil fuel costs, limited fuel sources and environmental concerns. Comparing to other clean energy resources, biomass is an exclusively sustainable renewable resource capable of producing petroleum-like products due to its hydrocarbon content (Dickerson and Soria, 2013). Current biomass conversion technologies for hydrocarbon production are biological, biochemical and thermochemical processes (Demirbas, 2009).

Pyrolysis is one of the most promising thermochemical technologies as it can potentially transform cheap, local, and abundant lignocellulosic biomass into useful solid, liquid and gas products, when processed at temperatures between $400^{\circ} \mathrm{C}$ and $650^{\circ} \mathrm{C}$ in the absence of oxygen (Mohan et al., 2006). The pyrolysis technology is further classified into slow pyrolysis and fast pyrolysis categories, depending on heating rates and residence time with relatively slow heating rates ranged from $0.1-1^{\circ} \mathrm{C} / \mathrm{s}$ and unrestricted residence time from minutes to hours, traditional pyrolysis is considered as slow pyrolysis. In addition, a fast pyrolysis, a relatively new technology, occurs when the biomass is heated at a rate of 10 to $1000^{\circ} \mathrm{C} / \mathrm{s}$ with short residence time (Balat et al., 2009). Fast pyrolysis claims to produce high bio-oil yields and is considered more advantageous than slow pyrolysis (Balat et al., 2009). Chemically, during the pyrolysis process, the biomass decomposes into condensable volatile species, gasses and solid residue, also called bio-char. The volatile species are condensed in the form of a dark viscous liquid also known as bio-oil (Yaman, 2004). 
The bio-oil produced by biomass pyrolysis can be used as an alternative energy resource and it may be directly burned for various applications (Bridgwater and Peacocke, 2000). However, the polyphenol polymerization reactions take place in bio-oil during storage (Oasmaa, 2000). These processes gradually change the properties of bio-oil. The polymerizing reactions are intensified when the bio-oil is exposed to light, oxygen and temperatures above $80^{\circ} \mathrm{C}$. As a result, the viscosity of bio-oil can change from 10 to 10,000 cp (Oasmaa, 2000). Also, bio-oil has lower $\mathrm{pH}$ and higher solid and moisture contents than crude oil leading to storage, corrosion and combustion issues (Oasmaa, 2000).

Catalytic upgrading the volatiles is currently considered as the most promising method to minimize the negative characteristics of bio-oil (Bridgwater, 1996). During the catalytic process, the moisture and oxygen contents of bio-oil are minimized, molecular weight is reduced, and some bio-oil mass is reduced in favor of char and gaseous species (Sekiguchi and Shafizadeh, 1984). The ideal catalyst should be highly active, selective to particular products, resistant to deactivation, readily recycled and cheap. Different catalysts have different reaction mechanisms. Currently, researchers are focusing on two main routes for upgrading; hydrodeoxygenation (HDO) and zeolite cracking. However, both of them have drawbacks. $\mathrm{HDO}$ requires large quantities of $\mathrm{H}_{2}$ at relatively high pressure while zeolite cracking produces relatively low bio-oil yields (Dickerson and Soria, 2013). Chen et al. (2008) pyrolyzed pine wood at $350^{\circ} \mathrm{C}$ with several additives including respectively: $\mathrm{NaOH}, \mathrm{Na}_{2} \mathrm{CO}_{3}, \mathrm{Na}_{2} \mathrm{SiO}_{3} \mathrm{NaCl}, \mathrm{TiO}_{2} \mathrm{HZSM}-5, \mathrm{H}_{3} \mathrm{PO}_{4}$ and $\mathrm{Fe}_{2}\left(\mathrm{SO}_{4}\right)_{3}$. During the pyrolysis, the main pyrolysis process were expressed as follows: 
Basic pyrolysis gasification reaction (Arauzo et al., 1994):

$$
C_{n} H_{m} O_{k}=\frac{m}{2} H_{2}+k C O+(n-k) C
$$

Further secondary gasification reactions:

$$
\begin{aligned}
& \mathrm{C}+\mathrm{H}_{2} \mathrm{O}=\mathrm{H}_{2}+\mathrm{CO} \\
& \mathrm{C}+\mathrm{CO}_{2}=2 \mathrm{CO} \\
& \mathrm{CO}+\mathrm{H}_{2} \mathrm{O}=\mathrm{H}_{2}+\mathrm{CO}_{2} \\
& \mathrm{CH}_{4}+\mathrm{H}_{2} \mathrm{O}=\mathrm{CO}+3 \mathrm{H}_{2}
\end{aligned}
$$

According to Chen et al. (2008), the alkaline sodium additives $\left(\mathrm{NaOH}, \mathrm{Na}_{2} \mathrm{CO}_{3}\right.$, $\mathrm{Na}_{2} \mathrm{SiO}_{3}$ ) have the most marked effect by decreasing the $\mathrm{CH}_{4}$ and $\mathrm{CO}_{2}$ formations and increasing the hydrogen formation. The mineral concentration of red oak bio-char is dominated by potassium, magnesium and calcium. These alkaline minerals have chemical characteristics similar to alkaline sodium.

Although bio-char has not been used as a catalyst in pyrolysis process, it has been successfully used in phenol and toluene cracking, biodiesel esterification catalyzing and methane reforming (Abbas and Wan Daud, 2009; Dehkhoda et al., 2010; Domínguez et al., 2007; Mani et al., 2013). Mani et al. (2013) used slow pyrolysis pine bark bio-char pyrolyzed at $900^{\circ} \mathrm{C}$ as a low-cost catalyst to decompose toluene. In this study, the catalytic conversion of toluene was studied in a continuous flow packed bed reactor system in the temperature range of $550-900{ }^{\circ} \mathrm{C}$ under atmospheric pressure. Streams of toluene and water vapors were added to the carrier gas (nitrogen) by two syringe pumps. The mixtures of nitrogen, toluene and water were then transported through a static mixer to the reactor, enclosed in a furnace, containing a $0.45 \mathrm{~m}$ preheating zone, followed by $0.03 \mathrm{~m}$ of catalyst 
(3.8 g catalyst or bio-char). A fractional conversion of $94 \%$ toluene was achieved on biochar catalysts (Mani et al., 2013). In another study, Dehkhoda et al. (2010) mixed $20 \mathrm{~g}$ of hardwood bio-char with $200 \mathrm{ml}$ concentrated sulfuric acid (98\%, Sigma) to prepare a sulfonated bio-char catalyst. The catalyst was very active in the esterification of free fatty acids and alcohols. To study the possibility of directly converting biogas to syngas, Domínguez et al. (2007) used pyrolyzed coffee hulls bio-char pellets as a potassium-rich catalyst during gasification of a mixture of $\mathrm{CH}_{4}$ and $\mathrm{CO}_{2}(1: 1$ ratio $)$. The study indicated that the gasification of $\mathrm{CH}_{4}$ to $\mathrm{H}_{2}$ increased and high conversion of $\mathrm{CH}_{4}$ was also achieved. In addition, bio-char may potentially lead to hydrogen formation during pyrolysis as it contains catalytic inorganic minerals (Aho et al., 2008; Chen et al., 2008; Dehkhoda and Ellis, 2013).

This paper studies the upgrading of pyrolysis vapors using bio-chars (red oak bark bio-char and switchgrass bio-char) its effects on yields and properties woodchip pyrolysis products. The objective of this research was to compare the influence of bio-char catalysis on ex-situ pyrolysis vapor upgrading during woodchip pyrolysis. Also the effects of catalyst loading were studied by changing the catalyst-to-biomass ratio 0.1 and 0.4 (by wt.). The term "bio-char" has been used for catalysts (switchgrass and red oak bark bio-chars) and the term "char" describes the residual solid product of woodchip pyrolysis.

\subsection{Method and Measurements}

\subsubsection{Description of pyrolysis reactor}

Pyrolysis experiments were performed in a fixed bed reactor with a nine-inch diameter and ten-inch height (Figure 3.1). The rector was sealed airtight with the biomass 
sample inside and then placed in a furnace (Model: BF51728C, Thermo Scientific, NC). To remove air from the sealed reactor, nitrogen gas was constantly purged at the rate of $2 \mathrm{~L} / \mathrm{min}$ during pyrolysis process. The furnace was heated from room temperature to $500{ }^{\circ} \mathrm{C}$ under a continuous nitrogen flow of $2 \mathrm{~L} / \mathrm{min}$. The nitrogen gas maintained the pyrolysis reaction under inert conditions. The nitrogen gas also swept the generated vapors into ice bath condensers. The ice bath consisted of five stainless-steel condensers (12" long and 4" diameter).The inner temperature of the reactor during pyrolysis process was continuously recorded by a K-type thermocouple placed at the center of the reactor inside a thermal well. The temperature data were automatically recorded by a data logger (Model: OM-DAQPRO5300, Omega engineering, Stamford, CT) connected to a computer.

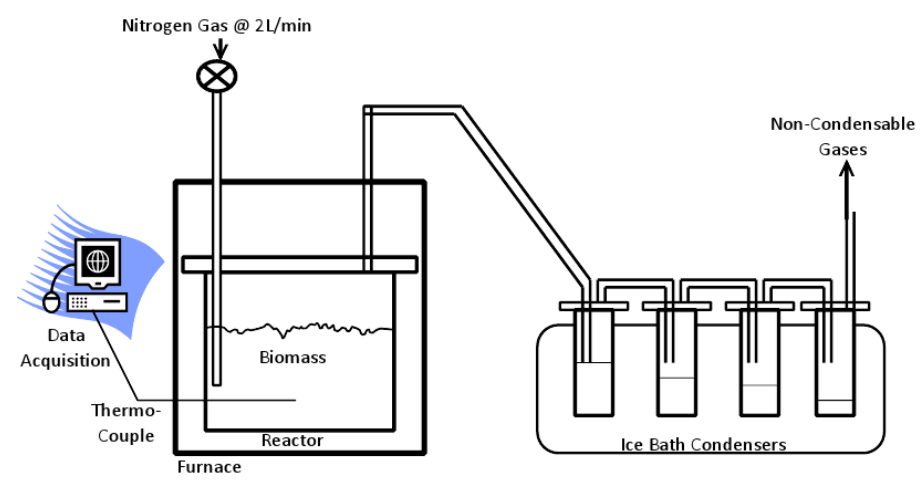

Figure 3.1. Experimental set-up used in pyrolysis includes pyrolysis reactor holding biomass, nitrogen flow, location of thermocouple, and set of condensers. 


\subsubsection{Pyrolysis Experiments}

Fresh samples of mixed wood chips were collected from a nearby sawmill. Samples of switchgrass were collected from a field where it was being grown for research purposes. Red oak bark was collected from a log of red oak harvested from the West Virginia University (WVU) Research Forest. All the samples were oven dried for 24 hours at $103{ }^{\circ} \mathrm{C}$ before pyrolysis. Prior to the pyrolysis experiments, the weights of the empty reactor and condensers were recorded. After that, about pre-weighted $1000 \mathrm{~g}$ (or half volume of the reactor) of biomass was placed inside the reactor. During heating of the sealed reactor, pyrolysis of the biomass occurred and volatiles were formed. The volatiles were condensed in the ice bath. The remaining uncondensed gases were filtered and released to the atmosphere. Before releasing the gases to the atmosphere, gas samples were collected when reactor temperature was 300,400 , and $500{ }^{\circ} \mathrm{C}$. The gas samples were collected using airtight GC syringes (Model: 1000 series, Hamilton, NV). After pyrolysis, the weights of the reactor with char inside and the condensers with bio-oil inside were recorded. The weight of char and bio-oil were calculated using the reactor and condenser weights recorded before and after reaction. This allowed the pyrolysis product yields to be calculated. The gas yield was calculated by difference.

To study catalytic upgrading of pyrolysis vapors, about 300-350 g of bio-char (switchgrass bio-char or red oak bark bio-char) were evenly placed on top of the woodchips. To produce catalyst bio-char from switchgrass and red oak bark, both of these biomasses were individually pyrolyzed at $500^{\circ} \mathrm{C}$ temperature. 


\subsubsection{Experimental design}

Completely Randomized Design was used to evaluate effects of three treatments. The three treatments were the use of no bio-char (control), switchgrass bio-char, and red oak bark bio-char for the catalytic refining of pyrolysis vapors. To do this, a layer of preweighted catalyst bio-char (switchgrass char or bark char) was evenly placed on top of the woodchips inside the reactor. This allowed the pyrolysis vapors to pass through the bio-char catalyst before condensation. The woodchips were pyrolyzed without bio-char catalysts as a control experiment. Each experiment was replicated twice, therefore a total of six experiments were performed. The char and bio-oil yield and data on the bio-oil properties were statistically analyzed to test the hypothesis that catalytic modification of pyrolysis vapors using bio-char catalysts reduces bio-oil yields.

\subsubsection{Analytical measurements}

The composition of gas samples were determined by a gas chromatograph (Model: Clarus GC 580, Perk Elmer Waltham, MA). In addition, the calorific value of woodchip char was measured using a bomb calorimeter (Model: 6300 Calorimeter, Parr Instrument Company, Moline, IL) according to the ASTM D5865 standard (Materials, 1998) without accounting for heat of reactions for nitric and sulfuric acids. It is important to mention that some bio-oil samples failed to ignite inside the bomb calorimeter. In such case the calorific value was determined using an empirical equation (Channiwala and Parikh, 2002). Ultimate analysis of char and bio-oil was performed using a CHNS analyzer (Model: Series II CNHS/O Analyzer 2400, PerkinElmer, Waltham, MA). Proximate analysis (moisture, volatile matter, fixed carbon and ash) was carried out using a proximate analyzer (Model: LECO 701, LECO Corporation, St. Joseph, MI, USA) following the ASTM 
D3174 standard (ASTM, 2011). The specific gravity and moisture content of bio-oil was measured according to ASME PTC 19.16 Standard and ASTM D4928 Standard, respectively. The moisture content was measured by a compact Karl Fisher titrator (Model: V30, Mettler Toledo, $\mathrm{OH})$. The $\mathrm{pH}$ value was measured by means of an accumet $\mathrm{pH}$ meter (Model: AB15, Fisher Scientific, USA). The bio-char catalysts were tested for mineral composition and chemical composition at the Agricultural and Environmental Sciences Laboratory, University of Georgia.

\subsubsection{Efficiency of char and bio-oil production}

The energy conversion efficiency $\left(\eta_{\text {Energy }}\right)$ and carbon yield $\left(C_{Y e i l d}\right)$ of wood chips char and bio-oil were estimated via the following expressions:

$$
\eta_{\text {Energy }}=Y_{\text {Char } / \text { bio-oil }} \frac{H H V_{\text {Char } / \text { bio-oil }}}{H H V_{\text {Feedstock }}}
$$

Where $\eta_{\text {Energy }}=$ energy conversion efficiency; $\mathrm{Y}_{\mathrm{Char} / \text { bio-oil }}=$ yield of bio-char or bio-oil $(\%) ; H H V_{\text {Char } / \text { bio-oil }}=$ calorific value of bio-char or bio-oil $(\mathrm{MJ} / \mathrm{kg})$; and $H H V_{\text {Feedstock }}=$ calorific value of the feedstock biomass.

$$
C_{\text {Yeild }}=Y_{\text {Char } / \text { bio-oil }} \frac{C_{\text {Char } / \text { bio-oil }}}{C_{\text {Feedstock }}}
$$

Where $C_{\text {Yeild }}=$ carbon yield; and $\mathrm{C}=$ carbon content of the feedstock, i.e.-char or bio-oil (\%) (Das, 2011). 


\section{3. Results and Discussion}

\subsubsection{Feedstock Biomass and Bio-char Catalyst Characterization}

Table 3.1 shows the ultimate analysis (carbon, hydrogen, nitrogen and sulfur contents), proximate analysis (moisture, ash, volatile and fixed carbon contents), and selected mineral contents of wood chip feedstock, and bio-char catalysts made from switchgrass and red oak bark. The $74.44 \%$ carbon content in red oak bark bio-char catalyst was significantly lower than the carbon content of $77.52 \%$ present in switchgrass bio-char catalyst (p-value=0.03). Similar carbon content $(78.3 \%)$ for switchgrass bio-char has been reported (Imam and Capareda, 2012). High carbon content in catalysts is expected to provide a more reactive carbon surface for refining of pyrolysis vapor refining. However, the fixed carbon content (ash-free basis) of red oak bark bio-char catalyst (77.78\%) was significantly higher than that of the switchgrass biochar catalyst (71.64\%). The difference between carbon content and fixed carbon content may be considered as reactive carbon which may actively take part in binding with oxygen present in the chemical compounds of pyrolysis vapors. This difference is more significant for switchgrass bio-char than for red oak bark bio-char, which again showed that the switchgrass bio-char catalyst has more reactive carbon than red oak bark biochar catalyst. At the same time, high ash-free carbon (fixed carbon) should provide a reducing matrix for vapor refining. Additionally, the ash content in switchgrass bio-char catalysts was $6.87 \%$, which was significantly higher than the ash content in red oak bark bio-char catalysts $(1.25 \%)$. High ash content represents high inorganic matter in biochars which should exhibit catalytic effects during the pyrolysis process. 
Mineral composition of switchgrass and red oak bark bio-chars are also presented in Table 3.1. Si and Al contents are of most important for catalytic purposes. Previous study found that simple ZSM-5 catalysts have a microporous crystalline structure containing oxides of $\mathrm{Si}$ and $\mathrm{Al}$ (Derouane et al, 1981). Also, the negatively charged $\mathrm{Al}_{3} \mathrm{O}_{4}{ }^{-}$, which provides acid reactive sites for cracking are created when $\mathrm{Al}_{3}{ }^{+}$substitutes for $\mathrm{Si}_{4}{ }^{+}$at appropriate places in the catalyst structure (Crook et al., 1993). In this case, the presences of $\mathrm{Al}$ and $\mathrm{Si}$ in ash, especially $\mathrm{Si}$ to $\mathrm{Al}$ ratio would be a vital factor to determine the reaction selectivity of catalysts. The Si to $\mathrm{Al}$ ratio for FCC (Fluidized Cracking Catalyst) catalyst is 1.84 (Gerber et al., 1999), and for ZSM-5 catalyst is 65.47 (Dao et al., 1987). In this study, the $\mathrm{Si}$ to $\mathrm{Al}$ ratio for switchgrass bio-char was 0.2 , and for red oak bark bio-char was 0.02 .

Table 3.1. Ultimate analysis (carbon, hydrogen, nitrogen and sulfur content (\% d.b.)), proximate analysis (moisture, ash, volatile and fixed carbon (\% d.b.)) of clean woodchip, switchgrass bio-char and red oak bark bio-char. Mineral composition in parts per million (ppm) of switchgrass biochar and red oak bark bio-char.

\begin{tabular}{llll}
\hline & Woodchip & $\begin{array}{l}\text { Switchgrass } \\
\text { Bio-char }\end{array}$ & $\begin{array}{l}\text { Red oak bark } \\
\text { Bio-char }\end{array}$ \\
\hline Carbon (\%) & $44.34 \pm 0.11$ & $77.52 \pm 0.78$ & $74.44 \pm 0.32$ \\
Hydrogen (\%) & $5.81 \pm 0.11$ & $2.65 \pm 0.03$ & $2.69 \pm 0.03$ \\
Nitrogen (\%) & $0.2 \pm 0.02$ & $1 \pm 0.12$ & $0.94 \pm 0.12$ \\
Sulfur (\%) & $0.49 \pm 0.09$ & $0 \pm 0$ & $0.2 \pm 0$ \\
Moisture (\%) & $5.8 \pm 0$ & $4.91 \pm 0.13$ & $2.85 \pm 0.34$ \\
Ash (\%) & $0.33 \pm 0.02$ & $6.87 \pm 0.18$ & $1.25 \pm 0.6$ \\
Volatile (\%) & $77.95 \pm 0.15$ & $16.59 \pm 0.83$ & $18.13 \pm 0.94$ \\
Fixed Carbon (\%) & $15.93 \pm 0.13$ & $71.64 \pm 0.51$ & $77.78 \pm 1.06$ \\
AL (ppm) & - & 48.73 & 156.60 \\
Cu (ppm) & - & 52.48 & 12.41 \\
Fe (ppm) & - & 40.46 & 108.30 \\
$\mathrm{Mn}(\mathrm{ppm})$ & - & 275.10 & 2161.00 \\
$\mathrm{Si}(\mathrm{ppm})$ & - & 9.75 & 3.70 \\
$\mathrm{Na}(\mathrm{ppm})$ & - & 260.50 & 44.46 \\
$\mathrm{Zn}(\mathrm{ppm})$ & - & 83.11 & 12.29 \\
$\mathrm{Ca}(\%)$ & - & 0.32 & 3.19 \\
$\mathrm{Mg}(\%)$ & - & 0.66 & 0.15 \\
$\mathrm{P}(\%)$ & - & 0.18 & 0.07 \\
$\mathrm{~K}(\%)$ & - & 1.71 & 0.24 \\
\hline
\end{tabular}




\subsubsection{Effect of Type of Bio-Char Catalysts}

\section{Bio-oil and Char Yields}

Table 3.2 shows the yields of char and bio-oil produced from woodchip pyrolysis. The gas yields were calculated by difference. The pyrolysis vapors were upgraded using bio-chars as catalysts prior to condensation. The catalyst loadings were kept $40 \%$ by weight. Two types of bio-char catalysts were tested: switchgrass bio-char and red oak bark bio-char. The woodchip without catalyst produced approximately $29 \%$ char and $49 \%$ bio-oil. In the literature, char and bio-oil yields for hardwood has been reported as: $15.90 \%$ char and $65.00 \%$ bio-oil were produced from beech wood in fluid-bed fast pyrolysis at $500^{\circ} \mathrm{C}$ (Greenhalf et al., 2013) and $23.01 \%$ char and $60.34 \%$ bio-oil were produced from commercial lignocellulose biomass (Lignocel HBS 150-500) originating from beech wood in fixed bed reactor through flash pyrolysis at $500^{\circ} \mathrm{C}$ (Stephanidis et al., 2011). In addition, Kim et al. reported that xylem tissues of oak produced $65.7 \%$ bio-oil and $14.1 \%$ bio-char, and xylem tissues of eucalyptus produced $59.2 \%$ bio-oil and $14.9 \%$ bio-char at $500^{\circ} \mathrm{C}$ in fluid-bed through fast pyrolysis (Kim et al., 2013). One possible reason of the relatively low bio-oil yield and high char yield observed in the present study could be due to the different moisture content of feedstock and type of pyrolysis used. Both studies referred above had used room temperature air drying method for feedstock drying. The moisture contents of the pyrolyzed biomass feedstock were 8\% (Greenhalf et al., 2013) and 5\% (Stephanidis et al., 2011). In contrast, the present study used oven-dried (bone-dried) biomass at temperature $103{ }^{\circ} \mathrm{C}$. In another study, Galina Dobele (2007) reported that the water content in bio-oil decreased to $19-20 \%$ from $25-28 \%$ in bio-oil after drying the wood sample with moisture 
content $8.5-9 \%$ at $200^{\circ} \mathrm{C}$ for 30 minutes (Galina Dobele, 2007). Another reason could be the particle size of feedstock, the woodchip size, not the average particle size, in this study was ranged from $1 / 2 " \times 1 / 2 " \times 1 / 10 "$ to $2 " \times 2 " \times 1 / 5 "$, in addition, the particle size of Kim et al was $0.5 \mathrm{~mm}$, which was much smaller than the woodchip size used in this study. Gaston et al. reported that larger particles led to more tar and char formation because less volatile were produced during the pyrolysis process (Gaston et al., 2011). There is another possibility getting small char yields when using very small particles for pyrolysis. During pyrolysis of very small particles, the char might be pneumatically carried from the reactor into the bio-oil condensers and contribute to the overall weight of the bio-oil.

In addition, heating rate also greatly affects bio-oil yield. Onay reported that high heating rate will result in high bio-oil yield. The yield of bio-oil was 7 wt. \% higher at heating rate $300{ }^{\circ} \mathrm{C} / \mathrm{min}$ than at heating rate $100{ }^{\circ} \mathrm{C} / \mathrm{min}$ (Onay, 2007). The average heating rate achieved in the present study was around $9{ }^{\circ} \mathrm{C} /$ min which was significantly lower than the $500-1000{ }^{\circ} \mathrm{C} / \mathrm{s}$ in previous study.

Table 3.2. Percent char and bio-oil yields (mean \pm SD, replications $=2$ ) produced from pyrolysis of clean woodchip at $500^{\circ} \mathrm{C}$ followed by catalytic upgrading of pyrolysis vapors using bio-char catalysts made from switchgrass and red oak wood bark. The catalyst to woodchip ratio (by weight) was kept approximately 0.40 .

\begin{tabular}{lllll}
\hline & Loading & Char & Bio-oil & Gas \\
\hline No catalyst & 0 & $29.09 \pm 0.22$ & $49.31 \pm 0.08$ & $21.61 \pm 0.31$ \\
Switchgrass catalyst & 0.4 & $28.56 \pm 1.60$ & $46.81 \pm 0.67$ & $24.63 \pm 0.93$ \\
Red oak bark catalyst & 0.4 & $29.82 \pm 0.56$ & $48.68 \pm 1.12$ & $21.51 \pm 0.56$ \\
\hline
\end{tabular}

Analysis of variance, for catalyst to woodchip loading of 0.4 , showed that the type of catalysts had significant effect on bio-oil yields ( $p$-value= 0.041). Between the two catalytic bio-chars, the switchgrass bio-char had a more profound effect on bio-oil yields 
than red oak bark bio-char $(\mathrm{p}$-value $=0.033)$. In fact, the switchgrass bio-char catalyst reduced bio-oil yields from $49.31 \%$ (no catalysis) to $46.81 \%$ ( $\mathrm{p}$-value $=0.022$ ). The different catalytic performances of the two bio-char catalysts could be caused by the differences of $\mathrm{Si}$ to $\mathrm{Al}$ ratios. The $\mathrm{Si}$ to $\mathrm{Al}$ ratio in switchgrass bio-char was ten times higher than that in red oak bark bio-char. In this case, more $\mathrm{Al}_{3}{ }^{+}$substitutes for $\mathrm{Si}_{4}{ }^{+}$at the surface of the switchgrass bio-char and consequently creates more reactive sites for vapor cracking.

As expected, the ex-situ catalytic vapor upgrading of pyrolysis volatiles did not affect residual char yields from woodchip pyrolysis. The yields of residual chars were $28.56 \%$ and $29.82 \%$ when woodchips were pyrolyzed with switchgrass bio-char and red oak bark bio-char, respectively. In contrast, Stephanidis et al. reported that the total char yields were affected during ex-situ catalytic upgrading of pyrolysis vapors. According to Stephanidis et al., commercial lignocellulose biomass (Lignocel HBS 150-500) originating from beech wood produced, approximately, 25.72\% char (out of which $2.71 \%$ was coke deposited on sillicatlite catalyst), $25.88 \%$ char (out of which $2.87 \%$ was coke deposited on H-ZSM-5 catalyst) and 30.66\% char (out of which 7.65\% was coke deposited on Al-MCM41 catalyst) (Stephanidis et al., 2011), while the non-catalyst char yield was $23.01 \%$. The main cause for the contrasting results was that Stephanidi et al. also accounted for the secondary char formation in the catalysis reactor. During in-situ catalysis, Compton et al. reported increases in char yields for oak pellets from $26.0 \%$ (no catalysis) to $37.1 \%-48 \%$ when different types of catalysts were mixed with the oak pellet biomass.

It is expected that ex-situ catalysts would alter bio-oil yields and its properties. The yields of bio-oil were $46.26 \%$ and $49.86 \%$ due to $e x$-situ catalysis with switchgrass bio-char and red oak bark bio-char, respectively. Stephanidis et al. reported commercial 
lignocellulose biomass (Lignocel HBS 150-500) originating from beech wood produced $47.58 \%, 43.95 \%$ and $45.34 \%$ bio-oil yields through vapor upgrading of pyrolysis gases by using catalyst sillicatlite, H-ZSM-5 and AI-MCM-41, respectively (Stephanidis et al., 2011). Among these three catalyst, H-ZSM-5 showed the most effectiveness, which was observed in another study as well (Huber, 2006). The measured catalytic activity was attributed to the strong Brönsted-type zeolitic acidity of H-ZSM-5. Oil yields of oak pellets ranged from $39.9 \%$ to $58.9 \%$ were produced in a packed bed at $500^{\circ} \mathrm{C}$ when the oak pellets were mixed with various catalyst pellets as biomass-to-catalyst ratio of 1:5 (Compton et al., 2011). Both Compton et al.'s and Stephanidis et al.'s studies used mesoporous aluminosilicates as the catalyst, however the yield results varied between in-situ and ex-situ catalysts. The change in char yield in in-situ catalytic pyrolysis (17.99\%) was higher than in ex-situ pyrolysis (7.66\%), while the change in liquid yield in in-situ catalytic pyrolysis (9.6\%) was lower than in the ex-situ process (14.89\%).

\section{Effect of Catalyst Loading on Char and Bio-oil Yields}

Table 3.3 presents pyrolysis product yields for two catalyst loading ratios of 0.1 and 0.4 for switchgrass bio-char catalyst during woodchips pyrolysis. As shown in Table 3.3, there is no significant difference between yields of char due to catalyst loading of 0.4 compared to that with no catalyst condition ( $\mathrm{p}$-value $=0.23$ ). Adding switchgrass catalyst at a loading ratio of 0.4 reduced bio-oil yield from $49.31 \%$ (no catalyst) to 44.81 . Changing catalyst loading from 0.1 to 0.4 reduced bio-oil yields from $46.81 \%$ to $44.81 \%$. The decrease in bio-oil yield may very well be explained by increased gas yields (Table 3.3). Thangalazhy-Gopakumar et al., (2012) varied catalyst ( $\left.\mathrm{H}^{+} \mathrm{ZSM}-5\right)$ from zero to nine times the biomass weight during pyrolysis of algae at $500{ }^{\circ} \mathrm{C}$. They found that increasing catalyst 
loading decreased the overall bio-oil yields. However, yields of aromatic hydrocarbons increased from 0.9 to $25.8 \%$ due to the presence of more active sites on the catalyst (Thangalazhy-Gopakumar et al., 2012).

Table 3.3. Percent char and bio-oil yields (mean \pm SD, replication=2) produced from pyrolysis of clean woodchip at $500^{\circ} \mathrm{C}$ followed by catalytic upgrading of pyrolysis vapors using bio-char catalysts made from switchgrass with different catalyst to woodchip ratio (by weight) as 0.1 and 0.4 .

\begin{tabular}{lllll}
\hline & Loading & Char & Bio-oil & gas \\
\hline No catalyst & 0 & $29.09 \pm 0.22$ & $49.31 \pm 0.08$ & $21.61 \pm 0.31$ \\
Switchgrass bio-char catalyst & 0.1 & $28.56 \pm 1.6$ & $46.81 \pm 0.67$ & $24.63 \pm 0.93$ \\
Switchgrass bio-char catalyst & 0.4 & $26.74 \pm 1.05$ & $44.81 \pm 1.4$ & $28.45 \pm 0.35$ \\
\hline
\end{tabular}

\section{Changes in Pyrolysis Gas Composition}

Table 3.4 shows gas composition of pyrolysis gasses generated at 300, 400, and $500{ }^{\circ} \mathrm{C}$ at a catalyst-to-biomass ratio of 0.4 . Ex-situ bio-char catalysis affected gas composition at all three temperatures $\left(300,400\right.$, and $\left.500^{\circ} \mathrm{C}\right)$ for which gases were sampled. At $300^{\circ} \mathrm{C}$, both bio-chars catalytically produced more $\mathrm{CO}$ and $\mathrm{CO}_{2}$ than the control condition ( $\mathrm{p}$-value<0.001). When comparing two bio-chars, the red oak bark bio-char produced more carbon dioxide and monoxide $(\mathrm{p}$-value $=0.0014)$. However, at temperature $400^{\circ} \mathrm{C}$, there is no significant difference of methane and $\mathrm{CO}$ release due to the addition of the either bio-chars but more hydrogen was released due to the use of switchgrass bio-char catalyst $(3.74 \%)$ than red oak bark bio-char catalyst $(0.48 \%) \quad(\mathrm{p}$-value $=0.0129)$ and control $(0.82 \%)$ (p-value=0.0186). The $\mathrm{CO}_{2}: \mathrm{CO}$ ratio was in the range of $1.5: 1$ to $2: 1$ at all three temperatures. Previous study by Compton et al. (2011) has reported $\mathrm{CO}_{2}: \mathrm{CO}$ of 1:1 when the oak pellets were mixed with various catalyst in a biomass-to-catalyst ratio of 1:5 in a packed bed at $500^{\circ} \mathrm{C}$ (Compton et al., 2011). Also, in Compton et al.'s study, the amounts of 
$\mathrm{CO}$ and $\mathrm{CO}_{2}$ were significantly higher than that of the control. However, in Stephanidis et al.'s study, the yield of $\mathrm{CO}_{2}$ was significantly decreased from $55.17 \%$ to $42.57,38.68$ and 45.42\%, when commercial lignocellulose biomass (Lignocel HBS 150-500) originating from beech wood was pyrolyzed and vapors were upgraded through sillicatlite, H-ZSM-5 and AI-MCM-41catalysts, respectively. The yields of CO and ethylene were significantly increased (Stephanidis et al., 2011). It may be concluded that bio-char catalysts gasify biooil compounds into carbon dioxide, carbon monoxide, and hydrogen, thereby, reducing total bio-oil yields.

Table 3.4. Percent of gas compositions (mean $\pm \mathrm{SD}$, replication=2) produced during vapor upgrading pyrolysis of clean woodchip at $300^{\circ} \mathrm{C}, 400^{\circ} \mathrm{C}$ and $500^{\circ} \mathrm{C}$ followed by catalytic upgrading of pyrolysis vapors using bio-char catalysts made from red oak bark and switchgrass loaded as catalyst to woodchip ratio (by weight) 0.4 .

\begin{tabular}{llllllll}
\hline $300^{\circ} \mathrm{C}$ & $\mathrm{O}_{2}$ & $\mathrm{H}_{2}$ & $\mathrm{CO}_{2}$ & Ethylene & Ethane & Methane & $\mathrm{CO}$ \\
\hline No Catalyst & $18.59 \pm 0.03$ & $0.01 \pm 0$ & $0.83 \pm 0.03$ & $0 \pm 0$ & $0 \pm 0$ & $0.19 \pm 0.01$ & $0.06 \pm 0.08$ \\
Red oak bark bio-char & $4.41 \pm 0.28$ & $0.45 \pm 0.13$ & $28.23 \pm 0.65$ & $0.2 \pm 0.25$ & $0.57 \pm 0.37$ & $6.5 \pm 0.81$ & $20 \pm 2.26$ \\
Switchgrass bio-char & $4.91 \pm 0.11$ & $0.13 \pm 0.01$ & $24.53 \pm 0.08$ & $0 \pm 0$ & $0 \pm 0$ & $0.69 \pm 0$ & $10.85 \pm 0.04$ \\
\hline $400^{\circ} \mathrm{C}$ & & & & & & & \\
\hline No Catalyst & $6.46 \pm 9.13$ & $0.82 \pm 1.16$ & $21.16 \pm 23.94$ & $0.45 \pm 0.64$ & $0.99 \pm 1.39$ & $6.3 \pm 7.23$ & $16.49 \pm 19.79$ \\
Red oak bark bio-char & $4.05 \pm 0$ & $0.48 \pm 0$ & $44.8 \pm 0$ & $0.39 \pm 0$ & $1.29 \pm 0$ & $8.93 \pm 0$ & $24.24 \pm 0$ \\
Switchgrass bio-char & $0.47 \pm 0.01$ & $3.74 \pm 0.99$ & $32.33 \pm 0.35$ & $0.7 \pm 0.06$ & $1.94 \pm 0.06$ & $10.13 \pm 0.07$ & $23.19 \pm 0.12$ \\
\hline 500 ${ }^{\circ} \mathrm{C}$ & & & & & & & \\
\hline No Catalyst & $0.56 \pm 0.13$ & $2.97 \pm 2.31$ & $22.88 \pm 4.84$ & $0.65 \pm 0.22$ & $1.36 \pm 0.43$ & $7.66 \pm 1.62$ & $18.64 \pm 4$ \\
Red oak bark bio-char & $8.12 \pm 0.16$ & $0.62 \pm 0.1$ & $29.35 \pm 0.11$ & $0.67 \pm 0.01$ & $1.96 \pm 0.07$ & $10.69 \pm 0$ & $19.07 \pm 0.08$ \\
Switchgrass bio-char & $5.85 \pm 0.04$ & $0.74 \pm 0.05$ & $19.6 \pm 0.06$ & $0.33 \pm 0.02$ & $1 \pm 0.06$ & $5.96 \pm 0.05$ & $12.78 \pm 0.01$ \\
\hline
\end{tabular}

\section{Char and Bio-oil Properties}

Table 3.5 shows the $\mathrm{pH}$ and moisture content in bio-oil produced from catalytic pyrolysis of woodchips using two catalysts (red oak bark bio-char and switchgrass bio-char) and without catalyst. The $\mathrm{pH}$ values of bio-oil produced from vapor upgrading pyrolysis $(\mathrm{pH}=2.02$ for the red oak bark bio-char catalyst and $\mathrm{pH}=2.23$ for the switchgrass bio-char 
catalyst) were significantly higher than non-catalytic pyrolysis (p-value=0.0009). Also, between the two catalysts, switchgrass bio-char showed more effect on the $\mathrm{pH}$ value than red oak bark bio-char catalyst ( $\mathrm{p}$-value=0.0029). High $\mathrm{pH}$ value should, relatively, decrease the corrosive activity of the bio-oil, and lower the material corrosion resistivity requirement for the reactor and containers. Similar results were presented by previous studies (Agblevor et al., 2010; Compton et al., 2011). The pH value increased from 1.63 to as high as 3.08 when the oak pellets were pyrolyzed with various catalyst (Compton et al., 2011). Also, the $\mathrm{pH}$ value increased from 2.82 to 3.45 when hybrid poplar wood was pyrolyzed with an ExxonMobil catalyst HZSM-5 at $500{ }^{\circ} \mathrm{C}$ (Agblevor et al., 2010).

Table 3.5. $\mathrm{pH}$ and percentage moisture content (mean $\pm \mathrm{SD}$, replication=2) in the bio-oil produced from woodchip pyrolysis at $500^{\circ} \mathrm{C}$ followed by catalytic upgrading of pyrolysis vapors using bio-char catalysts made from switchgrass and red oak wood bark. The catalyst to woodchip ratio (by weight) was kept approximately 0.4 .

\begin{tabular}{llll}
\hline & Loading & $\mathrm{pH}$ & Moisture content (\%) \\
\hline No catalyst & 0 & $1.9 \pm 0.07$ & $44.37 \pm 4.43$ \\
Red oak bark bio-char catalyst & 0.4 & $2.02 \pm 0.02$ & $51.97 \pm 6.73$ \\
Switchgrass bio-char catalyst & 0.4 & $2.23 \pm 0.05$ & $51.83 \pm 3.02$ \\
\hline
\end{tabular}

In addition, moisture content significantly increased from $44.37 \%$ to as high as $51.97 \%$ after vapor upgrading was performed using the two bio-char catalysts. Previous studies also reported an increase in water fraction in bio-oil. In one report, the non-catalytic bio-oil moisture content in bio-oil was $21.40 \%$ for beech wood pyrolysis reactions (Stephanidis et al., 2011). The moisture content increased from $21.40 \%$ to $30.80 \%, 33.97 \%$ and $30.06 \%$ when beech wood pyrolysis vapors were upgraded using sillicatlite, H-ZSM-5 and AI-MCM-41catalysts, respectively. The increased water fraction was attributed to enhanced dehydration reactions (Stephanidis et al., 2011). 
The calorific value (HHV) of bio-oil was calculated by the method presented by Channiwala et al. (Channiwala and Parikh, 2002). The method is presented below with an average absolute error of $1.45 \%$ and bias error of $0.00 \%$ :

$$
\begin{aligned}
& \mathrm{HHV}=0.3491 \mathrm{C}+1.1783 \mathrm{H}+0.1005 \mathrm{~S}-0.10340-0.0151 \mathrm{~N} \\
& \quad 0 \% \leqslant \mathrm{C} \leqslant 92.25 \%, 0.43 \% \leqslant \mathrm{H} \leqslant 25.15 \%, 0.00 \% \leqslant \mathrm{O} \leqslant 50.00 \%, 0.00 \% \leqslant \mathrm{~N}
\end{aligned}
$$

$\leqslant 5.60 \%, 0.00 \% \leqslant \mathrm{~S} \leqslant 94.08 \%, 0.00 \% \leqslant \mathrm{~A} \leqslant 71.4 \%, 4.745 \mathrm{MJ} / \mathrm{kg} \leqslant \mathrm{HHV} \leqslant 55.345 \mathrm{MJ} / \mathrm{kg}$ where, C, H, O, N, S and A represents carbon, hydrogen, oxygen, nitrogen, sulfur and ash contents of material, respectively, expressed in mass percentages on a dry basis. When calculating calorific values for bio-oils, hydrogen and oxygen contents present in the form of moisture were discounted using moisture content data from the elemental analysis.

Table 3.6 presents ultimate analysis and calorific value of chars and bio-oils produced from woodchip pyrolysis with and without vapor upgrading. The catalysts used in this study did not significantly change either elemental composition or calorific values of chars and bio-oils (p-value $=0.4880$ ). Demribas $(2004)$ 's pyrolyzed trunkbarks at $500{ }^{\circ} \mathrm{C}$ without any catalyst and reported carbon contents and calorific values for resulting char and bio-oil. Demirbas reported $68.8 \%$ carbon content and $34.6 \mathrm{MJ} / \mathrm{Kg}$ calorific value in bio-oil, also, $87.9 \%$ carbon content and 33.2 MJ/Kg calorific value in chars (Demirbas, 2004). The different calorific values of bio-oil may attribute by the different measurement methods. Demribas used bomb calorimeter to collect the higher heating values. In addition, trunkbark has higher HHV (21.7 MJ/Kg) than the mixed woodchip used in this study. 
Table 3.6. Calorific value (HHV) and elemental composition (CHNS) of raw, Chars and biooils produced from woodchip with and without using switchgrass and red oak bark bio-chars as pyrolysis vapor upgrading catalysts at catalyst to biomass ratio loading of 0.4 at dry basis.

\begin{tabular}{|c|c|c|c|c|c|c|}
\hline & & Carbon (\%) & $\begin{array}{l}\text { Hydrogen } \\
(\%)\end{array}$ & $\begin{array}{l}\text { Nitrogen } \\
(\%)\end{array}$ & Sulfur $(\%)$ & $\begin{array}{l}\mathrm{HHV} \\
(\mathrm{MJ} / \mathrm{Kg})\end{array}$ \\
\hline \multirow[t]{3}{*}{ No catalyst } & Raw & $44.34 \pm 0.11$ & $5.81 \pm 0.11$ & $0.2 \pm 0.02$ & $0.49 \pm 0.09$ & $19.17 \pm 0.76$ \\
\hline & Char & $86.72 \pm 0.94$ & $2.8 \pm 0.08$ & $0.59 \pm 0.16$ & $0 \pm 0$ & $33.12 \pm 0.18$ \\
\hline & Bio-oil & $54.95 \pm 4.16$ & $2.05 \pm 3.25$ & $0.81 \pm 0.11$ & $0.72 \pm 0.42$ & $19.28 \pm 4.53$ \\
\hline \multirow{2}{*}{$\begin{array}{l}\text { Red oak } \\
\text { bark } \\
\text { bio-char } \\
\text { catalyst }\end{array}$} & Char & $87.23 \pm 0.9$ & $2.71 \pm 0.05$ & $1.33 \pm 0.15$ & $0 \pm 0$ & $33.94 \pm 1.22$ \\
\hline & Bio-oil & $58.63 \pm 10.87$ & $0.67 \pm 0.87$ & $1.1 \pm 0.14$ & $0.88 \pm 0.39$ & $22.96 \pm 6.92$ \\
\hline \multirow{2}{*}{$\begin{array}{l}\text { Switchgrass } \\
\text { bio-char } \\
\text { catalyst }\end{array}$} & Char & $85.79 \pm 2.05$ & $2.94 \pm 0.16$ & $2.13 \pm 1.52$ & $0.06 \pm 0.09$ & $32.44 \pm 0.78$ \\
\hline & Bio-oil & $54.32 \pm 7.81$ & $1.94 \pm 2.75$ & $0.74 \pm 0.46$ & $0.98 \pm 0.21$ & $17.65 \pm 3.73$ \\
\hline
\end{tabular}

Energy and Carbon distribution

Table 3.7 presents feedstock energy and carbon distribution in char and bio-oil (water free basis). Both of the energy yield and carbon yield of bio-oil were not significantly affected by the catalyst ( $\mathrm{p}$-value $=0.5026$; $\mathrm{p}$-value $=0.2618$ ). Woodchips pyrolysis captured $50.30 \%$ of the feedstock energy and $56.67 \%$ of the carbon in the char and $27.58 \%$ of the feedstock energy and $31.72 \%$ of the feedstock carbon in the bio-oils. Overall, pyrolysis products (char and bio-oil) captured $77.88 \%$ feedstock energy and $88.39 \%$ feedstock carbon.

Also, the carbon yields in chars ( $\mathrm{p}$-value $=0.6757)$ were not significantly affected by the use of catalyst. However, switchgrass bio-char catalysis reduced the energy yield in char from $50.30 \%$ to $47.31 \%$ (p-value $=0.005)$ and it had a more pronounced affect than red oak bio-char catalysis ( $\mathrm{p}$-value $=0.026)$. The energy yield $(50.30 \%)$ of char produced from red oak bark bio-char catalysis was significantly higher than the energy yield of char $(50.30 \%)$ produced from non-catalytic pyrolysis $(\mathrm{p}$-value $=0.0236)$ and switchgrass bio-char catalytic pyrolysis ( $\mathrm{p}$-value $=0.005)$. 
Table 3.7. Energy and carbon distribution of bio-char and bio-oil yield (dry basis) from clean wood chips, and using switchgrass and red oak bark bio-chars as pyrolysis vapor upgrading catalyst (catalyst to biomass ratio of 0.4 ).

\begin{tabular}{llll}
\hline & & Energy yield (\%) & Carbon yield (\%) \\
\hline No catalyst & Cchar & $50.30 \pm 0.67$ & $56.67 \pm 1.11$ \\
& Bio-oil & $27.58 \pm 7.26$ & $31.72 \pm 0.78$ \\
\hline Switchgrass bio-char catalyst & Cchar & $47.31 \pm 0.16$ & $55.95 \pm 5.65$ \\
& Bio-oil & $19.06 \pm 4.63$ & $25.06 \pm 3.08$ \\
\hline Red oak bark bio-char catalyst & Char & $52.52 \pm 0.99$ & $59.02 \pm 1.10$ \\
& Bio-oil & $25.20 \pm 7.09$ & $34.06 \pm 7.09$ \\
\hline
\end{tabular}

Therefore, on average, the pyrolysis process is successful in retaining $78 \%$ of the energy and $89 \%$ of the carbon from the feedstock in its pyrolysis products. The carbon present in chars is a fixed form of carbon, which does not decompose naturally.

\subsection{Conclusion}

In this study, effect of bio-char catalysis for ex-situ refining of pyrolysis vapors was documented. The pyrolysis product yield showed that using switchgrass bio-char as a catalyst for refining pyrolysis vapors significantly reduced bio-oil yields from $49.37 \%$ to 44.81\%. Among the two bio-chars tested for pyrolysis vapor refining, the switchgrass biochar was more effective than red oak bio-char, possibly due to its high $\mathrm{Si} / \mathrm{Al}$ ratio. The $\mathrm{Si} / \mathrm{Al}$ ratio of switchgrass bio-char was 0.2 whereas the same ratio for red oak bio-char was 0.024 . Analyses of gas samples collected at 300,400 , and $500{ }^{\circ} \mathrm{C}$ revealed that the switchgrass biochar vigorously gasified bio-oil compounds at 300 and $400{ }^{\circ} \mathrm{C}$ into carbon monoxide, hydrogen, and carbon dioxide. At $400{ }^{\circ} \mathrm{C}$, hydrogen content increased from $0.82 \%$ to $3.74 \%$, carbon dioxide content increased from $21.16 \%$ to $32.33 \%$, and carbon monoxide content increased from $16.49 \%$ to $23.19 \%$ for the switchgrass catalyst compared to pyrolysis with no catalyst. It was also inferred from the results that changing catalyst loading from 0.1 to 
0.4 for the switchgrass catalyst also reduced bio-oil yields. Use of switchgrass not only reduced bio-oil yields, it also increased moisture content in the product bio-oils.

The significance of the study is that it provides a basis for developing selected biochars further into pyrolysis vapor refining catalysts. The results clearly demonstrate that the bio-chars having high $\mathrm{Si} / \mathrm{Al}$ ratio exhibit cracking characteristics. Some biomass with such properties are switchgrass and rice husk. The bio-chars produced from these biomass may be further modified for enhanced catalytic properties. These enhancements include: activation of bio-chars, acidification of bio-chars, and deposition of metals on bio-chars. 


\section{References}

Abbas, H. F., and W. M. A. Wan Daud. 2009. Thermocatalytic decomposition of methane using palm shell based activated carbon: Kinetic and deactivation studies. Fuel Processing Technology 90(9):1167-1174.

Agblevor, F. A., S. Beis, O. Mante, and N. Abdoulmoumine. 2010. Fractional catalytic pyrolysis of hybrid poplar wood. Industrial \& Engineering Chemistry Research 49(8):3533-3538.

Aho, A., N. Kumar, K. Eränen, T. Salmi, M. Hupa, and D. Y. Murzin. 2008. Catalytic pyrolysis of woody biomass in a fluidized bed reactor: Influence of the zeolite structure. Fuel 87(12):2493-2501.

Arauzo, J., D. Radlein, J. Piskorz, and D. S. Scott. 1994. A new catalyst for the catalytic gasification of biomass. Energy \& Fuels 8(6):1192-1196.

ASTM Committee on Standards. 1998. Standard test method for gross calorific value of coal and coke. Standard No. ASTM D5865-98a. The American Society for Tesing and Materials: West Conshohocken, PA, USA.

ASTM Committee on Standards. 2011. Standard test method for ash in the analysis sample of coal and coke from coal. Standard No. ASTM D3174-12. The American Society for Tesing and Materials: West Conshohocken, PA, USA.

ASTM Committee on Standards. 2013. Standard test method for water in crude oils by coulometric karl fischer titration. Standard No. ASTM D4928-12. The American Society for Tesing and Materials: West Conshohocken, PA, USA.

Balat, M., M. Balat, E. Kirtay, and H. Balat. 2009. Main routes for the thermo-conversion of biomass into fuels and chemicals. Part 1: Pyrolysis systems. Energy Conversion and Management 50(12):3147-3157.

Bridgwater, A. V. 1996. Production of high grade fuels and chemicals from catalytic pyrolysis of biomass. Catalysis Today 29(1-4):285-295.

Bridgwater, A. V., and G. V. C. Peacocke. 2000. Fast pyrolysis processes for biomass. Renewable and Sustainable Energy Reviews 4(1):1-73.

Channiwala, S. A., and P. P. Parikh. 2002. A unified correlation for estimating HHV of solid, liquid and gaseous fuels. Fuel 81(8):1051-1063.

Chen, M.-q., J. Wang, M.-x. Zhang, M.-g. Chen, X.-f. Zhu, F.-f. Min, and Z.-c. Tan. 2008. Catalytic effects of eight inorganic additives on pyrolysis of pine wood sawdust by microwave heating. Journal of Analytical and Applied Pyrolysis 82(1):145-150. 
Compton, D. L., M. A. Jackson, D. J. Mihalcik, C. A. Mullen, and A. A. Boateng. 2011. Catalytic pyrolysis of oak via pyroprobe and bench scale, packed bed pyrolysis reactors. Journal of Analytical and Applied Pyrolysis 90(2):174-181.

Dao, L. H., M. Haniff, A. Houle, and D. Lamothe. 1987. Reactions of biomass pyrolysis oils over ZSM-5 zeolite catalysts. 260 Prepr. Pap. Amer. Chem. Soc. Div. Fuel Chem $32: 308$

Das, K. C. S., K.; Bibens, B.; Hilten, R.; Baker, S. A.; Greene, W. D.; Peterson, J. D. 2011. Pyrolysis characteristics of forest residues obtained from different harvesting methods. Applied Engineering in Agriculture 27(1):107-113.

Dehkhoda, A. M., and N. Ellis. 2013. Biochar-based catalyst for simultaneous reactions of esterification and transesterification. Catalysis Today 207:86-92.

Dehkhoda, A. M., A. H. West, and N. Ellis. 2010. Biochar based solid acid catalyst for biodiesel production. Applied Catalysis A: General 382(2):197-204.

Demirbas, A. 2004. Determination of calorific values of bio-chars and pyro-oils from pyrolysis of beech trunkbarks. Journal of Analytical and Applied Pyrolysis 72(2):215-219.

Dickerson, T., and J. Soria. 2013. Catalytic fast pyrolysis: A Review. Energies (19961073) 6(1):514-538.

Domínguez, A., Y. Fernández, B. Fidalgo, J. J. Pis, and J. A. Menéndez. 2007. Biogas to syngas by microwave-assisted dry reforming in the presence of char. Energy \& Fuels 21(4):2066-2071.

Demirbas, F. M. 2009. Biorefineries for biofuel upgrading: A critical review. Applied Energy 86, Supplement 1:S151-S161.

Galina Dobele, I. U., Aleksandr Volpert, Valdis Kampars, Eriks Samulis. 2007. Fast pyrolysis - effect of wood drying on the yiedl and properties of bio-oil. BioResouces 2(4).

Gaston, K. R., M. W. Jarvis, P. Pepiot, K. M. Smith, W. J. Frederick, and M. R. Nimlos. 2011. Biomass pyrolysis and gasification of varying particle sizes in a fluidized-bed reactor. Energy \& Fuels 25(8):3747-3757.

Gerber, M. A., J. G. Fyre, L. E. Bowman, J. L. Fulton, L. J. Silva, and C. M. Wai. 1999. Regeneration of hydrotreating 275 and FCC catalysts. PNNL-13025 Pacific Northwest National Laboratory, Richland WA. 
Greenhalf, C. E., D. J. Nowakowski, A. B. Harms, J. O. Titiloye, and A. V. Bridgwater. 2013. A comparative study of straw, perennial grasses and hardwoods in terms of fast pyrolysis products. Fuel 108:216-230.

Huber, G. W. I., Sara \& Corma, Avelino. 2006. Synthesis of transportation fuels from biomass: chemistry, catalysts, and engineering. Chem. Rev. 106(9):4044--4098.

Imam, T., and S. Capareda. 2012. Characterization of bio-oil, syn-gas and bio-char from switchgrass pyrolysis at various temperatures. Journal of Analytical and Applied Pyrolysis 93:170-177.

Kim, K. H., T.-S. Kim, S.-M. Lee, D. Choi, H. Yeo, I.-G. Choi, and J. W. Choi. 2013. Comparison of physicochemical features of biooils and biochars produced from various woody biomasses by fast pyrolysis. Renewable Energy 50:188-195.

Mani, S., J. R. Kastner, and A. Juneja. 2013. Catalytic decomposition of toluene using a biomass derived catalyst. Fuel Processing Technology 114(0):118-125.

Mohan, D., C. U. Pittman, and P. H. Steele. 2006. Pyrolysis of wood/biomass for bio-oil: A critical review. Energy \& Fuels 20(3):848-889.

Oasmaa, A. 2000. Fuel oil quality of biomass pyrolysis oils-state of the art for the end users. Fuel and Energy Abstracts 41(5):298.

Onay, O. 2007. Influence of pyrolysis temperature and heating rate on the production of bio-oil and char from safflower seed by pyrolysis, using a well-swept fixed-bed reactor. Fuel Processing Technology 88(5):523-531.

Sekiguchi, Y., and F. Shafizadeh. 1984. The effect of inorganic additives on the formation, composition, and combustion of cellulosic char. Journal of Applied Polymer Science 29(4):1267-1286.

Stephanidis, S., C. Nitsos, K. Kalogiannis, E. F. Iliopoulou, A. A. Lappas, and K. S. Triantafyllidis. 2011. Catalytic upgrading of lignocellulosic biomass pyrolysis vapours: Effect of hydrothermal pre-treatment of biomass. Catalysis Today 167(1):37-45.

Thangalazhy-Gopakumar, S., S. Adhikari, S. A. Chattanathan, and R. B. Gupta. 2012. Catalytic pyrolysis of green algae for hydrocarbon production using H+ZSM-5 catalyst. Bioresource Technology 118:150-157.

Yaman, S. 2004. Pyrolysis of biomass to produce fuels and chemical feedstocks. Energy Conversion and Management 45(5):651-671. 


\section{CHA P T ER 4: SU M M A R Y}

In the first phase of this study, the pyrolysis kinetics of different wood polymers (cellulose, hemicellulose and lignin) and wood physical components (bark, sapwood and heartwood) were compared. The isoconversion method was applied to estimate activation energy of wood polymers and wood physical components during decomposition. In the second phase of this study, switchgrass bio-char and red oak bark bio-char were tested as catalysts during vapor upgrading of pyrolysis products. The catalyst performance was evaluated by measuring char and bio-oil yields and the characterization of bio-oil and char produced from vapor upgrading during pyrolysis of woodchips.

Results from the first phase of the study showed no significant difference for the results of the cell-wall specific gravity, calorific value and ultimate analysis among bark, sapwood and heartwood for red oak and yellow-poplar. In addition, cellulose showed activation energy values in the range of 208 to $381 \mathrm{~kJ} / \mathrm{mol}$ during decomposition whereas xylan and lignin had maximum activation energy values of $348 \mathrm{~kJ} / \mathrm{mol}$ and $801 \mathrm{~kJ} / \mathrm{mol}$ at fractional conversions of 0.4 and 0.5 , respectively. The activation energy requirement for wood components remained within the range of $233 \mathrm{~kJ} / \mathrm{mol}$ to $388 \mathrm{~kJ} / \mathrm{mol}$ until $365^{\circ} \mathrm{C}$ and then peaked to roughly $943 \mathrm{~kJ} / \mathrm{mol}, 449 \mathrm{~kJ} / \mathrm{mol}$ and $298 \mathrm{~kJ} / \mathrm{mol}$ for bark, heartwood and sapwood, respectively at $375^{\circ} \mathrm{C}$ where major energy input for lignin decomposition was needed. Also, it was observed that the isoconversion methods may not work for all the fractional conversion values for individual wood polymers but the method worked well for the wood components. 
The results of the second phase of the study showed that both catalysts at the loading ratio of 0.4 (by weight) had a significant effect on bio-oil yields. The bio-oil yield decreased from $49.31 \%$ (no catalyst) to $44.81 \%$ (switchgrass bio-char catalyst) and $48.68 \%$ (red oak bark bio-char catalyst). Additionally, there was no significantly change in char yields.

Use of a catalyst changes some bio-oil properties (moisture content and $\mathrm{pH}$ ). Moisture content increased from $44.37 \%$ to roughly $52.0 \%$. Increase in $\mathrm{pH}$ of bio-oil was also recorded due to the presence of catalyst. In addition, the gas composition changed due to presence of catalysts. For example, switchgrass bio-char cracked some bio-oil compounds at 300 and $400{ }^{\circ} \mathrm{C}$ into carbon monoxide, hydrogen, and carbon dioxide. At $400{ }^{\circ} \mathrm{C}$, the hydrogen content increased from $0.82 \%$ to $3.74 \%$, carbon dioxide content increased from $21.16 \%$ to $32.33 \%$, and carbon monoxide content increased from $16.49 \%$ to $23.19 \%$ for pyrolysis with switchgrass catalyst compared to that with no catalyst. Additionally, to use of catalyst decreased the carbon yield in bio-oil when using switchgrass bio-char as catalyst. 